\title{
Advances in the diagnostic imaging of pheochromocytomas
}

\author{
This article was published in the following Dove Press journal: \\ Reports in Medical Imaging \\ 10 May 201I \\ Number of times this article has been viewed
}

\author{
Eva Forssell-Aronsson' \\ Emil Schüler' \\ Håkan Ahlman² \\ 'Department of Radiation Physics, \\ ${ }^{2}$ Department of Surgery, Lundberg \\ Laboratory of Cancer Research, \\ Institute of Clinical Sciences, \\ Sahlgrenska Academy at the \\ University of Gothenburg, \\ Sahlgrenska University Hospital, \\ Gothenburg, Sweden
}

\begin{abstract}
Pheochromocytomas (PCs) and paragangliomas (PGLs) are routinely localized by computed tomography (CT), magnetic resonance imaging (MRI), and metaiodobenzylguanidine (MIBG) scintigraphy. CT can identify tumors with high sensitivity but rather low specificity. MRI has higher sensitivity and specificity than $\mathrm{CT}$ and is superior to detect extra-adrenal disease. Radioiodinated MIBG scintigraphy has been used for more than 30 years and is based on MIBG uptake via the norepinephrine transporter on the cell membrane. The technique is very useful for whole-body studies in case of multiple primary tumors or metastases. Tumors with sole production of dopamine usually cannot be visualized with MIBG and may require positron emission tomographic (PET) studies with ${ }^{18} \mathrm{~F}$-labeled radiotracers. Somatostatin receptor scintigraphy (SRS) using the radiolabeled somatostatin analog octreotide (based on the expression of the somatostatin receptors 2 and 5 by the tumor) can demonstrate PGL or metastases not visualized by MIBG. In this article, we review the use of MIBG scintigraphy to diagnose PC/PGL and compare the sensitivity and specificity with that of CT and MRI. We also describe the recent SRS and PET techniques and review the latest results of clinical studies by comparing these imaging modalities. Future perspectives of functional imaging modalities for PC/PGL are finally presented.
\end{abstract}

Keywords: MIBG, scintigraphy, pheochromocytoma, paraganglioma, PET

\section{Introduction}

Pheochromocytomas (PCs) and paragangliomas (PGLs) are rare tumors derived from the adrenal medulla or sympathetic/parasympathetic nervous tissue; PC and sympathetic PGL have excess secretion of catecholamines (CAs). About 10\% of PCs are malignant, but the prevalence of malignant tumors is higher for PGL (especially for the hereditary forms with mutations of the succinate dehydrogenase $\mathrm{B}(S D H B)$ gene). A significant number of so-called benign tumors will overtime develop metastases. ${ }^{1,2}$ Today, there is no reliable method that can distinguish benign from malignant tumors other than the presence of metastases. Patients with PC/PGL are, therefore, annually controlled biochemically for CAs and metabolites, and upon positive tests, whole-body imaging is performed using both computed tomography/magnetic resonance imaging (CT/MRI) and functional imaging techniques. ${ }^{3}$ Functional imaging (aimed at tumor localization and detection of CA secretion from each individual lesion) can be performed by scintigraphic visualization of a radioiodinated $\left({ }^{123} \mathrm{I}\right.$ or $\left.{ }^{131} \mathrm{I}\right) \mathrm{CA}$ analog (metaiodobenzylguanidine, MIBG), which is actively transported into the secreting tumor cells. MIBG scintigraphy has since long had a central role in the detection of PC/sympathetic PGL and metastases. It is also used for planning of radiotherapy using ${ }^{131} \mathrm{I}-\mathrm{MIBG}$, which is feasible at uptakes $>1 \%$
Correspondence: Eva Forssell-Aronsson Department of Radiation Physics, Lundberg Laboratory of Cancer Research, Institute of Clinical Sciences,

Sahlgrenska Academy at the University of Gothenburg, Sahlgrenska University Hospital, SE-4I 345 Gothenburg, Sweden Tel +463 I 3422349

Email eva.forssell_aronsson@radfys.gu.se 
of the injected dose. ${ }^{4}$ Recently developed functional positron emission tomography (PET)-CT techniques using specifically tailored CA molecules ( $\left[{ }^{18} \mathrm{~F}\right]$-dihydroxyphenylalanine $\left({ }^{18} \mathrm{~F}\right.$-DOPA $)$ or ${ }^{18} \mathrm{~F}$-dopamine $\left({ }^{18} \mathrm{~F}\right.$-DA $\left.)\right)$, or uptake and retention of 2-[ $\left.{ }^{18} \mathrm{~F}\right]$ fluoro-2-deoxy-D-glucose (FDG) by malignant cells, seem to have the highest sensitivity and specificity to correctly diagnose PC/PGL and metastases. ${ }^{5}{ }^{18} \mathrm{~F}-\mathrm{DOPA} / \mathrm{DA}$ PET is available only at few centers worldwide, which implies that MIBG scintigraphy will still remain the primary technique for functional imaging for several years to come.

Imaging techniques are routinely used for diagnosis of the neuroendocrine (NE) tumor types PC/PGL. The location and metastatic spread is of vital importance when evaluating the prognosis and treatment strategies. CT and MRI are sensitive tools in detecting the primary tumor but have restricted specificity. ${ }^{6}$ Therefore, functional imaging of the whole body is usually carried out using tumor-specific techniques, for example, uptake of radioiodine-labeled MIBG into the secretory granules of tumor cells. Scintigraphy using ${ }^{131}$ I-labeled MIBG has been widely used with some success for about 30 years. Today, there is a trend toward switching from ${ }^{131} \mathrm{I}-\mathrm{MIBG}$ to ${ }^{123} \mathrm{I}-\mathrm{MIBG}$. Different opinions have also been proposed regarding the usefulness of MIBG scintigraphy when compared to CT and MRI, with different recommendations for separate patient groups.

Many investigators recommend MIBG imaging prior to surgery, especially in patients with large $(>5 \mathrm{~cm})$, extra-adrenal, or multiple tumors. After successful surgery, biochemical testing is performed annually, followed by imaging studies when CA hypersecretion is indicated. In our own long-term population-based series of 154 patients with PC/PGL, we showed that only 12 patients had malignant tumors (8 PCs and 4 PGLs); the worst prognosis was found among the 4 patients presenting with distant metastases, while the tumor progression was slow for the 4 patients with locally advanced disease and the 4 patients who developed metastases despite benign appearance at primary surgery. ${ }^{2}$

The aim of this article is to summarize the current knowledge about the imaging methods used routinely or proposed for diagnosis of benign and malignant PC and PGL. Focus is directed toward MIBG scintigraphy, and results are discussed and compared with those of CT and MRI. The recent advances in PET techniques are included and compared with MIBG scintigraphy.

\section{Pheochromocytoma/paraganglioma}

Aminergic neurons and NE cells share the capacity to synthesize, store, and release biogenic amines. The amines are synthesized from precursor amino acids in the cytoplasm, followed by transport into storage granules by vesicular monoamine transporter molecules (VMATs) at the vesicular membrane. At stimulation, the amines are released from the granules by exocytosis. The two subtypes of VMATs (VMAT 1 and 2) are structurally similar but have different substrate specificity for serotonin, histamine, and CAs and have different tissue distribution. ${ }^{7}$ At the outer cell membrane, the norepinephrine transporter (NET) is responsible for the uptake of CA, or its analogs, from the circulation into sympathetic neurons and adrenal medullary cells. ${ }^{8}$

PC and sympathetic PGL are NE tumors derived from chromaffin cells of the adrenal medulla and sympathetic paraganglia (located along the sympathetic trunk in the thorax and abdomen and in the Zuckerkandls organ close to the aortic bifurcation). PGL can also be derived from the parasympathetic nervous system (mainly located in the head-neck region). Some nomenclature confusion has existed, that is, the term 'extra-adrenal PC' has been used to describe all PGL, but some authors have used PGL exclusively for parasympathetic PGL in the head-neck region. For the sake of clarity, we use PC for the intra-adrenal tumors and to distinguish between sympathetic (thoracoabdominal) and parasympathetic (head-neck) PGL. PC and sympathetic PGL can secrete CA, usually epinephrine (EPI) and/or norepinephrine, and more seldom DA. Hypersecretion of EPI/norepinephrine can cause hypertension, headache, palpitations, sweating, and anxiety, which can occur attack-wise (hypertensive crises) and lead to cerebrovascular and cardiac accidents. Parasympathetic PGL can cause local symptoms, but are not associated with excess secretion, even if they may express the acetylcholine transporter. $3,9,10$

The prevalence of PC/PGL is 0.8 per 100,000 per year. ${ }^{11}$ Since small and benign tumors with slow growth may be asymptomatic, or only cause vague symptoms, they can remain undiagnosed. This is one explanation for the higher prevalence figures seen in autopsy studies. ${ }^{12}$ The tumors are equally common in males and females and usually present at mid-life. ${ }^{13}$ Hereditary tumors are often diagnosed at younger age and $10 \%$ are present in children. ${ }^{14,15}$ Benign PC is usually located in one of the adrenal glands, while hereditary PC can be bilateral and multicentric. ${ }^{11}$ The hereditary tumors are part of familial syndromes, such as von Hippel-Lindau disease (VHL), neurofibromatosis type 1 (NF 1 ), multiple endocrine neoplasia type 2 (MEN 2), and the Carney syndrome. ${ }^{16,17}$ In VHL and NF 1 (incidence, 1:3000 each), the risk of developing PC is low; VHL is commonly associated with clear cell renal carcinoma and central nervous system hemangioblastoma, 
and NF 1 is associated with a variety of nerve-related tumors. In MEN 2A, a majority of patients will develop medullary thyroid carcinoma, one-half of them PC, and one-quarter hyperparathyroidism. The Carney syndrome is extremely rare (pulmonary hamartoma, gastrointestinal stromal tumor, and PC/sympathetic PGL). The familial PGL syndromes form a relatively new group of disorders with mutations in subunits of the mitochondrial enzyme succinate dehydrogenase (SDH): type 1 relates to benign parasympathetic PGL in the head-neck region with $S D H D$ mutations, ${ }^{18}$ type 2 was just recently described (SDH5 mutations), ${ }^{19}$ type 3 also relates to benign parasympathetic head-neck PGL (SDHC mutations), ${ }^{14}$ and type 4 is associated with sympathetic PGL with high risk for malignancy ( $S D H B$ mutations). ${ }^{20}$

Fumarate hydratase is another mitochondrial protein of the tricarboxylic acid cycle/respiratory chain, which in mutated form may lead to development of PC/PGL associated with hereditary leiomyomatosis and renal cell cancer. ${ }^{21}$ In addition, a fifth $\mathrm{SDH}$ protein (SDH 5 or SDH complex assembly factor 2, SDHAF 2) was recently shown to be a PGL-related tumor suppressor gene. ${ }^{22}$ Common for these mitochondrial genes is the stabilization of hypoxia inducible factor 1, leading to upregulation of glycolysis, glucose transport, and angiogenesis (Warburg effect). ${ }^{23}$ It is, therefore, likely that these tumors can be visualized via the glucose transporter irrespective of malignant transformation.

The majority of PC/PGL are benign. About $10 \%$ of all PCs are malignant, but this percentage is higher for abdominal sympathetic PGL (15\%-35\%) - even higher in the presence of SDHB mutations. ${ }^{24,25}$ Clinical, biochemical, or radiological features cannot distinguish benign from malignant tumors. ${ }^{3,13}$ No single histopathological features of a resected PC/PGL can predict future metastatic disease. Malignancy has, therefore, been defined as presence of metastases at sites where chromaffin tissue should not be present, for example, skeleton, lungs, liver, and lymph nodes. ${ }^{26}$ Malignant tumors are usually large with necrotic portions and are locoregionally invasive $^{27}$ and may extend into the caval vein, kidney, and liver. ${ }^{28}$ The lack of reliable malignancy predictors necessitates lifelong follow-up of PC/PGL patients.

\section{MIBG}

MIBG is a norepinephrine analog with iodine at the meta position in the benzoic ring. MIBG was developed at the University of Michigan Medical School in the late 1970s and was initially used for visualization of the adrenal medulla and myocardium. ${ }^{29-31}$ MIBG is taken up from the circulation by adrenergic/sympathomedullary tissues via NET at the cell membrane into the cytoplasm (type I uptake). This uptake is characterized by high affinity, saturability, and dependence of temperature, energy, and sodium. MIBG is then concentrated into intracytoplasmic storage vesicles via another specific uptake mechanism using the adenosine triphosphatase-dependent VMATs. Granularly stored MIBG can then be released by exocytosis. ${ }^{32-34}$ MIBG does not bind to postsynaptic adrenergic receptors and is claimed to be metabolized only to a very low extent..$^{32,35,36}$ The interaction between the NET and VMAT transporter systems has not been elucidated so far. In pilot studies, high scintigraphic uptake of ${ }^{123}$ I-MIBG was found in two malignant PGL with high VMAT expression (500-730 copies of VMAT1 and 1500-1700 copies of VMAT2 per 1000 copies of $\beta$-actin). A third malignant PGL had negative imaging and low VMAT expression (330 copies of VMAT1 and 350 copies of VMAT2 per 1000 copies of $\beta$-actin). In vitro, the VMAT antagonist reserpine and membrane pump inhibitors inhibited the uptake of ${ }^{123}$ I-MIBG into tumor cells equally well. ${ }^{37}$

MIBG can be radiolabeled by exchanging the stable iodine $\left({ }^{127} \mathrm{I}\right)$ with a radioactive iodine isotope, usually ${ }^{123} \mathrm{I}$ or ${ }^{131} \mathrm{I}$ for diagnostic and ${ }^{125} \mathrm{I}$ or ${ }^{131} \mathrm{I}$ for therapeutic purposes. Recently, ${ }^{124} \mathrm{I}-\mathrm{MIBG}$ has been proposed for PET studies. ${ }^{38}$ The physical properties of ${ }^{123} \mathrm{I}$ and ${ }^{131} \mathrm{I}$ are given in Table 1.

Table I Physical data on radionuclides of interest for scintigraphy of PC/PGL'29

\begin{tabular}{|c|c|c|c|}
\hline Radionuclide & $t_{1 / 2}$ & $\begin{array}{l}\text { Photon energy } \\
\text { (keV) (yield, \%) }\end{array}$ & $\begin{array}{l}\text { Electron energy } \\
(\mathrm{keV}) \text { (yield, \%) }\end{array}$ \\
\hline \multirow[t]{5}{*}{ |23| } & $13 \mathrm{~h}$ & $27-32(86)$ & $0.7-4.5(278)$ \\
\hline & & $127(14)$ & $22-30(12)$ \\
\hline & & $154(1.6)$ & $127(14)$ \\
\hline & & $159(83)$ & I54 (I.6) \\
\hline & & 529 (I.4) & \\
\hline \multirow[t]{6}{*}{$|3|$} & 8.0 days & $30(4.0)$ & $46(3.6)$ \\
\hline & & $80(2.6)$ & $69^{\prime}(2.1)$ \\
\hline & & $284(6.1)$ & $97^{\prime}(7.4)$ \\
\hline & & $364(81)$ & $192^{\prime}(89)$ \\
\hline & & $637(7.3)$ & $330(1.6)$ \\
\hline & & $723(1.8)$ & \\
\hline${ }^{11} \mathrm{C}$ & $20 \mathrm{~min}$ & $511(200)$ & $386^{\prime}(99.8)\left[\mathrm{e}^{+}\right]$ \\
\hline \multirow[t]{2}{*}{${ }^{18} \mathrm{~F}$} & $110 \mathrm{~min}$ & $511(193)$ & $250^{\prime}(96.7)\left[\mathrm{e}^{+}\right]$ \\
\hline & & & $0.52(3)$ \\
\hline \multirow[t]{8}{*}{${ }^{124} \mid$} & 4.2 days & $27-3 I^{\prime}(58.5)$ & $3.2^{\prime}(64.3)$ \\
\hline & & $511(45.8)$ & $23^{\prime}(8.3)$ \\
\hline & & $603(62.9)$ & $687^{\prime}(11.8)\left[\mathrm{e}^{+}\right]$ \\
\hline & & $723(10.4)$ & $975^{\prime}(10.8)\left[\mathrm{e}^{+}\right]$ \\
\hline & & $1326(1.6)$ & \\
\hline & & $1376(1.8)$ & \\
\hline & & I509 (3.3) & \\
\hline & & I691 (I.I) & \\
\hline
\end{tabular}

Note: 'Average energy.

Abbreviations: $\left[\mathrm{e}^{+}\right]$, positron energy; PC, pheochromocytoma; $\mathrm{PGL}$, paraganglioma. 
Using a similar exchange of the iodine atom with ${ }^{211} \mathrm{At}$, MABG has been produced and has been tested for therapy experimentally. ${ }^{39,40}$

MIBG is usually administered intravenously and is excreted mainly via the kidneys (about $85 \%$ ); $45 \%-60 \%$ of the administered activity is excreted during the first $24 \mathrm{~h}$. $^{32,41,42}$ Other excretion pathways are via the intestines, sweat, saliva, and exhalation..$^{35}$

Normal uptake of MIBG is frequently seen in organs and tissues rich in sympathetic innervation, for example, the myocardium, lungs, spleen, liver, cerebellum, urinary bladder, colon, and salivary glands. ${ }^{42-47}$ Uptake of ${ }^{123}$ I-MIBG is found in the heart and lungs in about $90 \%$ of the patients. ${ }^{33,45,48}$ Significant uptake in the large intestine can be seen in late imaging in about $15 \%$ of the patients when ${ }^{131}$ I-MIBG was used. ${ }^{42,44}$ Uptake in bone tissue does not seem to occur. ${ }^{44}$

Although MIBG was initially developed for visualization of the adrenal medulla, the normal adrenal medulla was rarely visualized with ${ }^{131} \mathrm{I}-\mathrm{MIBG}$, and a very faint adrenal uptake was reported in $<7 \%$ of the patients. . $^{32,41,49,50}$ On the other hand, other studies have demonstrated normal adrenal medulla accumulation of ${ }^{131}$ I-MIBG in up to $28 \%$ of the patients, with increasing visualization rate for higher administered activities. ${ }^{51-53}$ Using ${ }^{123}$ I-MIBG, uptake in the normal adrenal was more commonly visualized. Some studies reported visible adrenal medulla in about $30 \%$ of the patients, ${ }^{48,54}$ but even higher frequencies (50\%-80\%) have been obtained. ${ }^{49,50,55}$ The different results between the studies are interestingly not dependent of the given amount of ${ }^{123}$ I activity.

\section{MIBG scintigraphy}

\section{Scintigraphic procedures}

For scintigraphy, ${ }^{123} \mathrm{I}-$ or ${ }^{131} \mathrm{I}-\mathrm{MIBG}$ is slowly administered intravenously. According to the European Association of Nuclear Medicine recommendations, the amount of activity injected is $400 \mathrm{MBq}$ of ${ }^{123} \mathrm{I}-\mathrm{MIBG}$ and $40-80 \mathrm{MBq}$ of ${ }^{131}$ I-MIBG for adults, while for children, the administered activity should be scaled according to the body weight of the patient. ${ }^{56}$ Thyroid blockage is recommended, either by potassium iodide or potassium perchlorate, as an alternative when the patient is allergic to iodine..$^{41,56}$ The patient is recommended to drink fluids after administration and to void frequently in order to reduce the radioiodine activity in the bladder and thus facilitate for detection of lesions in the vicinity of the bladder. ${ }^{56}$ In addition, laxatives can be recommended when imaging the abdomen. ${ }^{41}$
Scintigraphic imaging with MIBG is performed using a large field-of-view gamma camera, usually equipped with a low-energy (LE) collimator $\left({ }^{123} \mathrm{I}\right)$ or a high-energy (HE) collimator $\left.{ }^{131} \mathrm{I}\right)$ (Figures $1 \mathrm{~B}$ and $2 \mathrm{~B}$ ). Both anterior and posterior planar views should be acquired together with single photon emission computed tomography (SPECT) for ${ }^{123}$ I-MIBG. When using the short-lived ${ }^{123}$ I, images are usually acquired at both 24 and 48 hours after injection. ${ }^{55,56}$ Although the optimal imaging time has been found to be 18-24 hours after injection with visual assessment, ${ }^{48}$ the 48-hour images can still be helpful; visualization of both intrathoracic and intra-abdominal lesions may be improved due to longer residence time of MIBG in PC/PGL than in normal tissues. ${ }^{48,56}$ Late images are better obtained with the long-lived ${ }^{131} \mathrm{I}$-MIBG than with ${ }^{123}$ I-MIBG. Imaging with ${ }^{131} \mathrm{I}$ should be obtained at 24,48 , and 72 hours after injection, with the option of even later images..$^{51,56}$ Maximal uptake is usually seen at 24-48 hours after injection..$^{43}$

\section{Sensitivity and specificity of MIBG scintigraphy}

A summary of the sensitivity and specificity of MIBG scintigraphy in various clinical studies is shown in Tables 2 and 3. The sensitivity of ${ }^{131} \mathrm{I}$-MIBG in detecting PC/PGL was $77 \%-90 \%$, with a specificity of $95 \%-100 \%$ (Table 2). The number of patients varied much in the studies reported. The study with the largest patient group in this review $(n=400)$ reported a sensitivity and specificity of $87 \%$ and $99 \%$, respectively, ${ }^{57}$ in line with the other large studies. A sensitivity of $100 \%$ was reported in two studies, but it should be noted that these studies were small

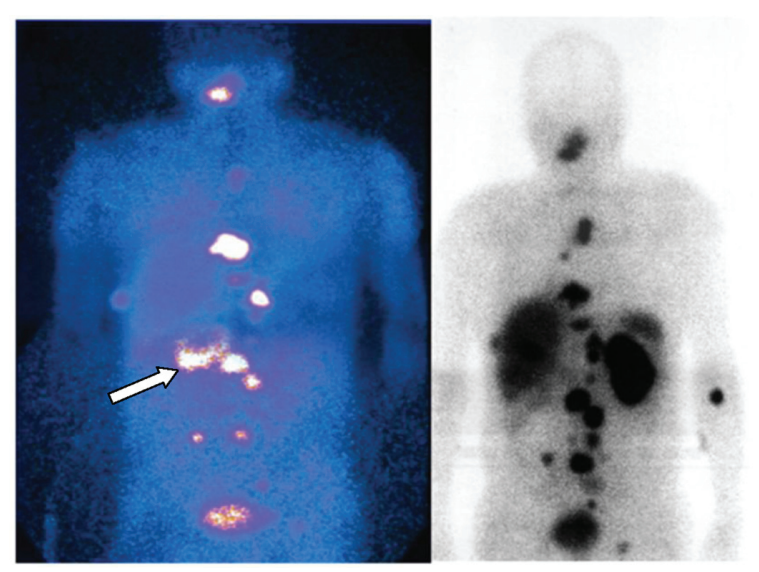

Figure I Male patient with a large, partly necrotic, malignant paraganglioma (arrow) with lymphoglandular and skeletal metastases imaged by SRS (left panel). After removal of the primary tumor together with the right kidney this patient underwent radiotherapy with ${ }^{|3|}$ I-MIBG. Subsequent imaging visualized more numerous lesions than SRS did (right panel). 


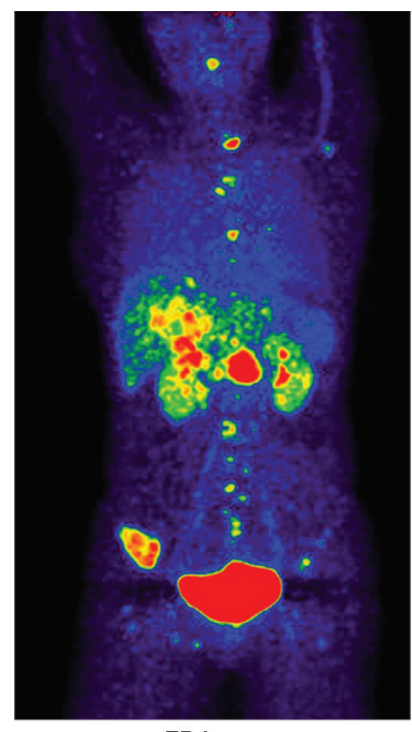

FDA
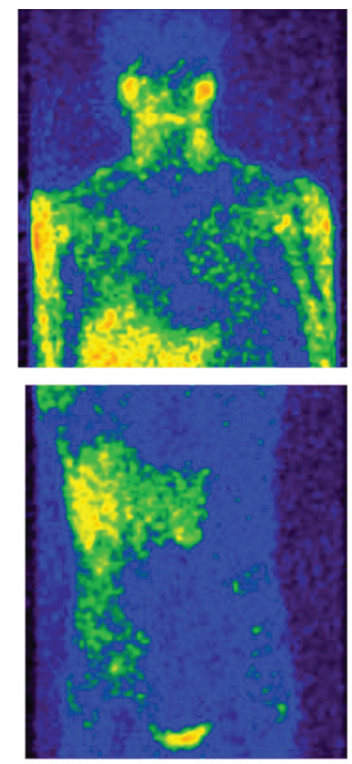

I-123 MIBG
Figure 2 I8F-FDA PET scan: Anterior reprojected image showing multiple metastatic paraganglioma lesions; ${ }^{123}$ I-MIBG SPECT: Anterior reprojected images do not visualize metastatic lesions that are seen on I8F-FDA PET (Pacak K and Clara C, NIH, unpublished images).

( $<10$ patients in each). ${ }^{58,59}$ In some of the studies, values were given separately for subgroups of PC/PGL. If only PGL was considered, the sensitivity was lower (58\%-89\%, based on four studies). The sensitivity for malignant disease was found to be $77 \%$ in one study and $92 \%$ in another study. Another study reported a sensitivity of $100 \%$ for malignant disease. ${ }^{60}$ The reason for this high value is probably that the main metastatic site was the skeleton. In general, the difference in detection rates between studies is probably related to a variable contribution of parasympathetic and sympathetic PGL to a main population of PC. Such subgroups were not defined in older studies.

Using ${ }^{123}$ I-MIBG scintigraphy, a sensitivity of $88 \%-96 \%$ and a specificity of $96 \%-100 \%$ have been reported (Table 3 ). The highest sensitivity was obtained in a study consisting only of PC patients. ${ }^{61}$ The lowest sensitivity was $75 \%,{ }^{62}$ which may be due to a large proportion of PGL. Some of these patients may have been parasympathetic head and neck PGL with a documented low sensitivity (44\%). ${ }^{61,63} \mathrm{In}$ a recent prospective, multicenter trial, where masked readers evaluated the images, the overall sensitivity was $81 \%-88 \%$ and specificity was $75 \%-84 \%$ for ${ }^{123}$ I-MIBG scintigraphy of primary and metastatic PC/PGL (Table 3). ${ }^{64}$

Recently, SPECT/CT is used more commonly and has the advantage of simultaneous acquisition of both morphological and functional data. Using ${ }^{123} \mathrm{I}-\mathrm{MIBG}$ SPECT/CT, it is possible to obtain a sensitivity and specificity of $100 \%{ }^{65}$
SPECT/CT can differentiate between tumor mass and scar tissue with exact anatomical details and can be useful in cases where diagnostic CT shows equivocal results. ${ }^{66,67}$

It is generally assumed that ${ }^{123} \mathrm{I}-\mathrm{MIBG}$ gives better image quality than ${ }^{131} \mathrm{I}-\mathrm{MIBG}$, especially better signal contrast and image resolution due to lower photon energy and detection efficiency (see below). The drawback is the shorter half-life limiting the possibility with late images when better contrast would be assumed. Several studies have confirmed better detection possibilities (higher sensitivity and specificity and better visualization of the smallest tumors) with ${ }^{123}$ I-MIBG scintigraphy. ${ }^{32,49,68-73}$

The MIBG uptake in PC/PGL may also be influenced by various drugs. The salivary glands, liver, and spleen are frequently seen in MIBG images. If no uptake is seen in the normal tissues with rich sympathetic innervation, suspicion should be raised whether the patient is taking medications, or drugs, that interfere with MIBG uptake. ${ }^{42-45}$ Examples of such medications are inhibitors of uptake (labetalol and calcium channel blockers) and storage depleters (reserpine, tricyclic antidepressants, and sympathomimetics). ${ }^{41,68,74}$ In addition, cocaine and antipsychotics may interfere with the MIBG uptake. ${ }^{33}$

The detection efficiency for ${ }^{123}$ I-MIBG seems to vary due to the type of tumor, for example, lower for malignant PC than for benign ones. It has also been reported that the ${ }^{123}$ I uptake in unilateral, intra-adrenal, and sporadic tumors is higher than in bilateral, extra-adrenal, and familial PC. ${ }^{75}$ This is in concordance with the findings of two other studies using ${ }^{131} \mathrm{I}$-MIBG. ${ }^{57,76}$ With the recent knowledge about the variation in genotype between different tumors (VHL, MEN 2, SDHB, SDHC, SDHD, and nonfamilial), it is likely that the imaging performance might differ between these types and also explain some of the diverging results seen in previous studies. $^{74}$

The intensity of MIBG uptake in malignant versus benign PC/PGL can be debated. One study showed that the MIBG uptake in the tumor was lower in malignant than in benign ones. ${ }^{75}$ In another study, the signal intensity ratio in malignant lesions was significantly higher than in benign ones. ${ }^{77}$ One important difference between these two studies is that the latter includes many patients with recurrent PC. Increased awareness in these cases may lead to earlier tumor detection. Early diagnosed recurrent $\mathrm{PC}$ also means lower risk of necrosis, that is, high MIBG uptake. It has been found that malignant PC/PGL is larger at the time of detection compared with benign ones $;{ }^{78}$ larger tumors have higher probability of necrosis with lower detection efficiency 
Table 2 Sensitivity and specificity of ${ }^{|3|} \mid$-MIBG scintigraphy for diagnosis of PC/PGL

\begin{tabular}{|c|c|c|c|}
\hline I31'I-MIBG study & $\begin{array}{l}\text { No. of patients and tumor } \\
\text { type according to the authors }\end{array}$ & Sensitivity (\%) & Specificity (\%) \\
\hline \multirow[t]{3}{*}{ Francis et $\mathrm{al}^{60}$} & $\mathrm{n}=32 \mathrm{PC}$ & 89 - extra-adrenal & Not reported \\
\hline & & 100 - intra-adrenal & \\
\hline & & $100-$ metastatic & \\
\hline Ackery et al ${ }^{43}$ & $\mathrm{n}=38 \mathrm{PC}$ & 89 & 95 \\
\hline Brown et $\mathrm{al}^{130}$ & $\mathrm{n}=40 \mathrm{PC}$ & 79 & 86 \\
\hline \multirow[t]{6}{*}{ Shapiro et $\mathrm{al}^{57}$} & $\mathrm{n}=400 \mathrm{PC}$ & 87 - overall & 99 - overall \\
\hline & & 78 - primary sporadic & 99 - primary sporadic \\
\hline & & 92 - malignant & 100 - malignant \\
\hline & & $94-$ familial & $100-$ familial \\
\hline & & 92 - intra-adrenal & \\
\hline & & 75 - extra-adrenal & \\
\hline Swensen et $\mathrm{a}^{\mid 31}$ & $\mathrm{n}=48 \mathrm{PC}$ & 77 & 96 \\
\hline Hoefnagel et al ${ }^{59}$ & $\mathrm{n}=9 \mathrm{PC}$ & 100 & 100 \\
\hline Bravo and Saha ${ }^{132}$ & $\mathrm{n}=109 \mathrm{PC}$ & 78 & 100 \\
\hline Campeau et al ${ }^{42}$ & $\mathrm{n}=24 \mathrm{PC}$ & 88 & 100 \\
\hline Clesham et $\mathrm{al}^{133}$ & $n=14 P C$ & 90 & 100 \\
\hline \multirow[t]{4}{*}{ Maurea et $\mathrm{al}^{77}$} & $\mathrm{n}_{\text {before surgery }}=21 \mathrm{PC}+\mathrm{PGL}$ & 82 - before surgery & 100 - both before and after surgery \\
\hline & & ( 14 benign and 3 malignant) & \\
\hline & $n_{\text {after surgery }}=19 P C+P G L$ & 85 - after surgery & \\
\hline & & ( 3 benign and 9 malignant) & \\
\hline Lucon et al ${ }^{78}$ & $\mathrm{n}=23 \mathrm{PC}$ & 88 & Not reported \\
\hline \multirow[t]{5}{*}{ Jalil et a $\left.\right|^{86}$} & $\mathrm{n}=160 \mathrm{PC}+\mathrm{PGL}$ & $81-$ total & 97 total \\
\hline & & 84 - adrenal total & \\
\hline & & 88 - unilateral & \\
\hline & & $62-$ bilateral & \\
\hline & & 64 - extra adrenal & \\
\hline Mannelli et $\mathrm{al}^{87}$ & $\mathrm{n}=115 \mathrm{PC}$ & 88 & Not reported \\
\hline Furuta et $\mathrm{al}^{68}$ & $\mathrm{n}=29 \mathrm{PC}$ & 86 & 100 \\
\hline \multirow[t]{4}{*}{ Nguyen et al ${ }^{76}$} & $\mathrm{n}=104 \mathrm{PC}$ & 87 - total & 99 total \\
\hline & Sensitivity and specificity & 91 - adrenal total & \\
\hline & calculated on lesions $(n=119)$ & 58 - extra-adrenal & \\
\hline & not on patients & 77 - malignancy & \\
\hline Witteles et $\mathrm{al}^{58}$ & $\mathrm{n}=8 \mathrm{PC}$ & 100 & Not reported \\
\hline \multirow[t]{5}{*}{ Huang et $\mathrm{a}^{80}$} & $\mathrm{n}=25 \mathrm{PC}$ & 80 & 100 \\
\hline & & 86 - unilateral & \\
\hline & & $91-$ if excluding $3 / 5 \mathrm{FN}$ which & \\
\hline & & were on labetalol therapy & \\
\hline & & 95 - unilateral & \\
\hline llias et $\mathrm{al}^{1 / 2}$ & $\mathrm{n}=16 \mathrm{PC}$ & 56 & Not reported \\
\hline \multirow[t]{2}{*}{ Timmers et al ${ }^{103}$} & $\mathrm{n}=6$ & $33-$ by patient before treatment & Not reported \\
\hline & Metastatic SDHB related PGL & 30 - by region before treatment & \\
\hline
\end{tabular}

Abbreviations: FN, false negative; PC, pheochromocytoma; PGL, paraganglioma; MIBG, metaiodobenzylguanidine; SDHB, succinate dehydrogenase B.

of MIBG. This explanation is also supported by the findings in a study of one patient examined repeatedly with ${ }^{123}$ I-MIBG scintigraphy, with whom the results changed from positive to negative, probably due to dedifferentiation during the tumor progression. ${ }^{62}$

False-negative results of MIBG scintigraphy may occur due to several reasons. One obvious factor is insufficient uptake of radioiodinated MIBG by the tumor. ${ }^{49}$ Many authors agree that there is a positive correlation between size and MIBG signal intensity. ${ }^{62,75,76}$ Most of these studies use only visual grading of the images. In a quantitative analysis, the concentration of ${ }^{131} \mathrm{I}$ in $\mathrm{PC} / \mathrm{PGL}$ given per gram of tumor tissue was in general similar for all tumors $(0.03 \%-0.09 \% \mathrm{IA} / \mathrm{g})$, with the exception for the largest tumor $(0.004 \% / g)$. This finding led the authors to hypothesize that larger tumors are less metabolically active and thus have lower uptake of ${ }^{131}$ I-MIBG. ${ }^{31}$ Other explanations may involve biological changes in the tumor tissue, for example, loss or reduced expression of the NET or VMAT transporters, dedifferentiation of the tumor, or necrosis formation. ${ }^{27,62,75,79}$ 
Table 3 Sensitivity and specificity of ${ }^{123}$-MIBG scintigraphy for diagnosis of PC/PGL

\begin{tabular}{|c|c|c|c|}
\hline${ }^{123}$ I-MIBG study & $\begin{array}{l}\text { No. of patients and tumor } \\
\text { type according to the authors }\end{array}$ & Sensitivity (\%) & Specificity (\%) \\
\hline Montravers et $\mathrm{a}^{61}$ & $\begin{array}{l}\mathrm{n}_{\mathrm{PC}}=63 \\
\mathrm{n}_{\mathrm{PGL}}=7 \\
\text { Sensitivity and specificity } \\
\text { calculated on examinations }\end{array}$ & $\begin{array}{l}96(\mathrm{PC}) \\
39(\mathrm{PGL})\end{array}$ & 96 \\
\hline Clesham et al ${ }^{133}$ & $\mathrm{n}=9 \mathrm{PC}$ & 83 & 100 \\
\hline Mozley et al ${ }^{54}$ & $\mathrm{n}=120 \mathrm{PC}$ & 88 (Grade 3 on grading system) & Not reported \\
\hline Mannelli et $\mathrm{al}^{87}$ & $\mathrm{n}=59 \mathrm{PC}$ & 90 & Not reported \\
\hline Furuta et $a^{168}$ & $\mathrm{n}=16 \mathrm{PC}$ & 90 & 100 \\
\hline van der Harst et $\mathrm{al}^{75}$ & $\begin{array}{l}\mathrm{n}=75 \mathrm{PC} \\
\text { Sensitivity and specificity calculated } \\
\text { on lesions }(\mathrm{n}=84) \text { not on patients }\end{array}$ & $\begin{array}{l}83 \\
90(>I \mathrm{~cm})\end{array}$ & 98 \\
\hline Hoegerle et al ${ }^{118}$ & $\mathrm{n}=14 \mathrm{PC}$ & 71 & Not reported \\
\hline Miskulin et $\mathrm{a}^{95}$ & $\begin{array}{l}\mathrm{n}=48 \mathrm{PC} \\
\text { known unilateral adrenal mass }\end{array}$ & 98 & Not reported \\
\hline Lumachi et a ${ }^{69}$ & $\mathrm{n}=32 \mathrm{PC}$ & 91 & 100 \\
\hline van der Horst-Schrivers et al ${ }^{134}$ & $\mathrm{n}=30 \mathrm{PC}$ & 92 & 100 \\
\hline Koopmans et $\mathrm{al}^{63}$ & $\mathrm{n}=29$ Parasympathetic PGL & 44 & Not reported \\
\hline Bhatia et $a^{62}$ & $\begin{array}{l}n=76 \text { PC Sensitivity and specificity } \\
\text { calculated on lesions }(n=93) \text { not } \\
\text { on patients }\end{array}$ & $\begin{array}{l}75 \text { - total } \\
85 \text { - adrenal } \\
58 \text { - extra-adrenal } \\
\text { ( } 8 / 14 \text { carotid body, } 2 / 2 \text { intrathoracic, } \\
8 / 14 \text { retroperitoneal, and } 2 / 3 \text { pelvic } \\
\text { PC demonstrated) }\end{array}$ & Not reported \\
\hline Wiseman et al ${ }^{64}$ & $\mathrm{n}=140$ & $82-$ total & $82-$ total \\
\hline Prospective study & & $\begin{array}{l}87-\mathrm{PC} \text { prior known } \\
67-\mathrm{PGL} \text { prior known } \\
88-\mathrm{PC} / \mathrm{PGL} \text { suspected } \\
85-\mathrm{PC} / \mathrm{PGL} \text { metastatic }\end{array}$ & $\begin{array}{l}73-P C \text { prior known } \\
\text { I00-PGL prior known } \\
84-\text { PC/PGL suspected }\end{array}$ \\
\hline Timmers et al ${ }^{103}$ & $\begin{array}{l}\mathrm{n}=20 \text { before treatment } \\
\mathrm{n}=10 \text { after treatment } \\
\text { Metastatic SDHB-related PGL }\end{array}$ & $\begin{array}{l}80 \text { - by patient before treatment } \\
65 \text { - by region before treatment } \\
60 \text { - by patient after treatment } \\
41 \text { - by region after treatment }\end{array}$ & Not reported \\
\hline Timmers et $\mathrm{al}^{5}$ & $\begin{array}{l}\mathrm{n}=20 \text { nonmetastatic } \mathrm{PGL} \\
\mathrm{n}=28 \text { metastatic }\end{array}$ & $\begin{array}{l}77 \\
57\end{array}$ & Not reported \\
\hline Ilias et al ${ }^{102}$ & $\begin{array}{l}\mathrm{n}=16 \text { nonmetastatic } \mathrm{PC} \\
\mathrm{n}=35 \text { metastatic } \mathrm{PC}\end{array}$ & $\begin{array}{l}88 \text { - by patient } \\
75-\text { by region } \\
71-\text { by patient } \\
59 \text { - by region } \\
76 \text { - overall by patient } \\
63 \text { - overall by region }\end{array}$ & \\
\hline
\end{tabular}

Abbreviations: PC, pheochromocytoma; PGL, paraganglioma; MIBG, metaiodobenzylguanidine; SDHB, succinate dehydrogenase B.

The reported detection limit for PC, that is, the smallest tumor volume detectable, can vary. One study reported that $\mathrm{PC}$ with negative ${ }^{123}$ I-MIBG examination (using visual grading) had a median diameter of $2.3 \mathrm{~cm}$, while detected tumors had a median diameter of $5.0 \mathrm{~cm} .{ }^{62}$ They also reported that all adrenal tumors $<2.4 \mathrm{~cm}$ remained undetected. Very little has been reported on extra-adrenal PC metastases with regard to the detection limit. Using ${ }^{131} \mathrm{I}-\mathrm{MIBG}, \mathrm{PC}$ and PGL tumors with a diameter $<3 \mathrm{~cm}$ were false negative in $17 \%$ of the cases, while tumors larger than that only gave falsenegative results in $10 \%$ of the cases. ${ }^{76}$ They also found that tumors with a volume of $<20 \mathrm{~cm}^{3}$ were false negative in $36 \%$, while tumors above this limit were only negative in $3 \%$ of the cases.

For PGL, a detection limit of $1-2 \mathrm{~cm}$ in diameter has been reported for ${ }^{123} \mathrm{I}-\mathrm{MIBG} .{ }^{48}$ Another study found that PGL with negative ${ }^{123} \mathrm{I}-\mathrm{MIBG}$ examination had a median diameter of $2.8 \mathrm{~cm}$, while positive lesions had a median diameter of $3.5 \mathrm{~cm}$; no significant correlation between tumor size and visual uptake of ${ }^{123}$ I-MIBG for PGL was demonstrated. ${ }^{62}$

In general, the images are evaluated visually; quantitative evaluation is only done occasionally, mainly for 
treatment planning prior to ${ }^{131} \mathrm{I}-\mathrm{MIBG}$ therapy. By visual examination of the positive scintigrams, it might be difficult to distinguish between PC, adrenal medullary hyperplasia, and normal physiological uptake. To increase the diagnostic accuracy, a few slightly different grading systems have been proposed. ${ }^{54,62,70,75}$ These grading systems have in common that they consist of a 4-point scale based on visual comparison between the signal intensity in the adrenal gland and that in the normal liver (with minor differences in definition of the scores). In one study including both PC and PGL, the correlation between application of a scoring system and postoperative histological findings demonstrated high sensitivity (92\%) and specificity (100\%); 63 of 67 patients were correctly diagnosed. ${ }^{70}$

In general, such grading systems and scores related to the signal intensity in normal tissues should be avoided due to several reasons: 1) the uptake in a normal tissue might vary considerably between different individuals and 2) in planar images, the visual signal from a small/thin potential tumor is strongly dependent both on the size (area) in the image (due to limited image resolution) and on the depth and thickness versus the reference tissue. Quantitative evaluation is, therefore, strongly recommended for planar scintigraphy. In SPECT, the effects of the second above-mentioned limitation are reduced at least for relatively large tumors, but the problem with interindividual variation in normal tissue uptake remains.

\section{Advantages and disadvantages with ${ }^{123} \mid$ and ${ }^{131} \mid$}

The physical properties of ${ }^{123} I$ and ${ }^{131} I$ are different (Table 1), which influence the imaging properties (Table 4). With ${ }^{123}$ I-MIBG, a higher sensitivity can be achieved compared with ${ }^{131}$ I-MIBG, which has to do with the numerous drawbacks of ${ }^{131}$ I when it comes to diagnostic-imaging performance. ${ }^{35,50}$ The photons emitted by ${ }^{131} \mathrm{I}$ have higher photon energy than optimal photon energy for use in modern gamma cameras, which requires the use of inefficient collimators lowering the contrast and spatial resolution of the image and reducing counting statistics. ${ }^{35}$ Furthermore, ${ }^{131} \mathrm{I}$ has a long half-life of 8 days, which contributes to high-radiation dose together with a large component of $\beta$-particles, which restricts the amount of activity that should be administered. However, the long halflife of ${ }^{131} \mathrm{I}$ allows delayed imaging, which can be of a certain value, since the retention time of ${ }^{131} \mathrm{I}-\mathrm{MIBG}$ in the adrenal medulla is longer than in the surrounding normal tissues. Late imaging with ${ }^{131}$ I-MIBG may thus reveal lesions with low uptake not detected when the background activity is high. ${ }^{35,49,80}$ The importance to acquire the images at optimal time points has been well demonstrated. ${ }^{51}$ For patients receiving higher amounts of ${ }^{131} \mathrm{I}$-MIBG (40 MBq), three lesions were visible at day 7 only and all but one lesion were better visualized on images taken after 7 days of administration.

With the use of ${ }^{123} \mathrm{I}$, better image quality can be achieved in general. The photon energy of $159 \mathrm{keV}$ for ${ }^{123} \mathrm{I}$ makes it highly suited for modern gamma cameras. The effective dose for ${ }^{123}$ I-MIBG is much lower than for ${ }^{131} \mathrm{I}-\mathrm{MIBG}$, which allows 15 times higher administered activity of ${ }^{123} \mathrm{I}$, without increasing the effective dose (Table 5). ${ }^{35}$ The combination of more suitable photon energy and lower effective dose gives an 80 -fold increase in useful photon flux, which results in a better ability to detect lesions and a more accurate definition of the lesion. ${ }^{35,41,50,75}$ Another benefit of using ${ }^{123} \mathrm{I}$ is the possibility to use SPECT in combination with planar scintigraphy. SPECT might enhance the possibility to delineate tumors, especially in regions with high activity in surrounding tissues, preferentially in the anterior-posterior direction. ${ }^{27}$ For these reasons, ${ }^{123} \mathrm{I}-\mathrm{MIBG}$ has replaced ${ }^{131} \mathrm{I}-\mathrm{MIBG}$ in many hospitals. ${ }^{62}$

${ }^{123} \mathrm{I}$ is more expensive than ${ }^{131} \mathrm{I}$ and has to be synthesized shortly before administration and is not commercially available in all countries. ${ }^{35,41}$ Another drawback with ${ }^{123} \mathrm{I}$ is the

Table 4 Comparison of ${ }^{13 \mid}$ I-MIBG and ${ }^{123}$ I-MIBG for scintigraphy of PC/PGL

\begin{tabular}{|c|c|c|}
\hline & ${ }^{123}|-M| B G$ & ${ }^{|3|} \mid-M I B G$ \\
\hline Photon energy & Suited for modern gamma cameras & $\begin{array}{l}\text { Higher than optimal. Requires inefficient } \\
\text { collimators which reduces contrast and spatial } \\
\text { resolution }\end{array}$ \\
\hline Radiation & Gamma, X-ray, Auger electrons & Beta, gamma, X-ray \\
\hline Delayed imaging & Up to $48 \mathrm{~h}$ & $\begin{array}{l}\text { Highly suited because of its longer half-life. } \\
\text { At least up to } 7 \text { days }\end{array}$ \\
\hline Radiation dosimetry & $\begin{array}{l}\text { Low-effective dose - } 80 \text {-fold increase in } \\
\text { useful photon flux compared to }{ }^{|3|} \mid\end{array}$ & High-effective dose \\
\hline Image quality & Superior & Inferior \\
\hline Uptake in nonpathologic adrenal gland & Common & $\begin{array}{l}\text { Rarely, if occurs, it is only very faint } \\
\text { adrenal uptake }\end{array}$ \\
\hline
\end{tabular}

Abbreviations: PC, pheochromocytoma; PGL, paraganglioma; MIBG, metaiodobenzylguanidine. 
Table 5 Comparison of absorbed doses to normal tissues and effective dose between radiopharmaceuticals used for scintigraphy of PC/PGL

\begin{tabular}{|c|c|c|}
\hline & \multicolumn{2}{|c|}{$\begin{array}{l}\text { Absorbed dose per unit activity } \\
\text { administered (mGy/MBq) }\end{array}$} \\
\hline & I31'I-MIBG' ${ }^{135}$ & ${ }^{123}$ I-MIBG ${ }^{136}$ \\
\hline Adrenals & I.7E-0| & I.7E-02 \\
\hline Bladder wall & $5.9 \mathrm{E}-0 \mathrm{I}$ & 4.8E-02 (bladder) \\
\hline Bone surfaces & 6.IE-02 & $\mathrm{I} . \mathrm{IE}-02$ \\
\hline Breast & $6.9 \mathrm{E}-02$ & $5.3 \mathrm{E}-03$ \\
\hline \multicolumn{3}{|l|}{ Gl tract } \\
\hline Stomach wall & 7.7E-02 & 8.4E-03 (stomach) \\
\hline Small intestine & $7.4 \mathrm{E}-02$ & $8.4 \mathrm{E}-03$ \\
\hline ULI wall & $8.0 \mathrm{E}-02$ & $9.1 \mathrm{E}-03$ \\
\hline LLI wall & $6.8 \mathrm{E}-02$ & $7.9 \mathrm{E}-03$ \\
\hline Heart & $7.2 \mathrm{E}-02$ & $1.8 \mathrm{E}-02$ \\
\hline Kidneys & $\mathrm{I} .2 \mathrm{E}-0 \mathrm{I}$ & $1.4 \mathrm{E}-02$ \\
\hline Liver & $8.3 \mathrm{E}-0 \mathrm{I}$ & 6.7E-02 \\
\hline Lungs & $1.9 \mathrm{E}-0 \mathrm{I}$ & $1.6 \mathrm{E}-02$ \\
\hline Ovaries & $6.6 \mathrm{E}-02$ & $8.2 E-03$ \\
\hline Pancreas & $\mathrm{I} .0 \mathrm{E}-0 \mathrm{I}$ & $1.3 \mathrm{E}-02$ \\
\hline Salivary glands & $2.3 \mathrm{E}-0 \mathrm{I}$ & $1.7 \mathrm{E}-02^{135}$ \\
\hline Red marrow & 6.7E-02 & $6.4 \mathrm{E}-03$ \\
\hline Spleen & $4.9 \mathrm{E}-0 \mathrm{I}$ & $2.0 \mathrm{E}-02$ \\
\hline Testes & $5.9 \mathrm{E}-02$ & 5.7E-03 \\
\hline Thyroid & $5.0 \mathrm{E}-02$ & $5.6 \mathrm{E}-03$ \\
\hline Uterus & $8.0 \mathrm{E}-02$ & I.IE-02 \\
\hline Other tissues & $6.2 \mathrm{E}-02$ & $6.7 \mathrm{E}-03$ \\
\hline \multicolumn{3}{|l|}{ Effective dose } \\
\hline 123| MIBG & \multicolumn{2}{|c|}{$1.3 \mathrm{E}-02 \mathrm{mSv} / \mathrm{MBq}^{136}$} \\
\hline |31। MIBG & \multicolumn{2}{|c|}{$2.0 \mathrm{E}-01 \mathrm{mSv} / \mathrm{MBq}^{135}$} \\
\hline In-I I I labeled-octreotide & \multicolumn{2}{|c|}{$5.4 \mathrm{E}-02 \mathrm{mSv} / \mathrm{MBq}^{136}$} \\
\hline F-I8 FDG & \multicolumn{2}{|c|}{$1.9 \mathrm{E}-02 \mathrm{mSv} / \mathrm{MBq}^{136}$} \\
\hline F-I8 DOPA & \multicolumn{2}{|c|}{$2.5 \mathrm{E}-02 \mathrm{mSv} / \mathrm{MBq}^{137}$} \\
\hline CT head & \multicolumn{2}{|c|}{$2 \mathrm{mSv}^{138}$} \\
\hline CT chest & \multicolumn{2}{|c|}{$8 \mathrm{mSv}^{138}$} \\
\hline CT abdomen & \multicolumn{2}{|c|}{$10 \mathrm{mSv}^{138}$} \\
\hline CT pelvis & \multicolumn{2}{|c|}{$10 \mathrm{mSv} \mathrm{v}^{138}$} \\
\hline
\end{tabular}

Abbreviations: PC, pheochromocytoma; PGL, paraganglioma; CT, computed tomography; MIBG, metaiodobenzylguanidine; DOPA, dihydroxyphenylalanine; ${ }^{18} \mathrm{~F}$-FDG, 2-[18$\left.{ }^{18} \mathrm{~F}\right]$ fluoro-2-deoxy-D-glucose; ULI, upper large intestine; LLI, lower large intestine.

increased uptake, which can be seen in normal adrenal gland tissue, which might obscure small lesions located there. ${ }^{48,75}$ The normal adrenal medulla is rarely visualized with ${ }^{131}$ I-MIBG; if so, the signal intensity is usually very low. ${ }^{32,41,49}$ It has been claimed that the same image quality as seen with diagnostic amounts of ${ }^{123} \mathrm{I}$ can only be obtained with therapeutic amounts of ${ }^{131} \mathrm{I} \cdot{ }^{49}$

\section{Aspects on measurement techniques}

In scintigraphy, the choice of detector collimator is very important to obtain a high contrast together with a reasonably high spatial resolution. The latter is especially important for SPECT. In general, scintigraphy of ${ }^{131} \mathrm{I}$ is performed with a HE collimator due to the high main photon energy (Tables 1 and 4), while ${ }^{123}$ I scintigraphy is performed either with a LE or with a medium-energy (ME) collimator. In a theoretical study, the effect of the choice of collimator was evaluated ${ }^{81}$ Both ${ }^{131} I$ and ${ }^{123} \mathrm{I}$ emit photons of higher energy than their main emission (Table 1); although the yield of these photons is low, they may cause a clear degradation of the image quality. These HE photons may cause an increased background signal mainly due to septal penetration in the collimator and Compton interaction in the detector. ${ }^{81}$

With an ME collimator, HE background signal contamination from ${ }^{123} \mathrm{I}-\mathrm{MIBG}$ is effectively decreased (eg, by reduced septal penetration), resulting in an increased signal contrast versus that from an LE collimator, but with a reduced spatial resolution. For quantitative studies using ${ }^{123} \mathrm{I}-\mathrm{MIBG}$, ME collimators might then be preferred. ${ }^{81-83}$ By applying scatter correction on images acquired with LE collimators, the contrast can be enhanced. Using triple energy window scatter correction, computer simulations indicate that the contrast is better with a low-energy high-resolution collimator than with an ME collimator. ${ }^{81}$ However, a phantom study showed that regardless of reconstruction method, scatter correction, and attenuation correction, ME collimators still gave more accurate signal-contrast values. ${ }^{82}$ Even though the detection of $364 \mathrm{keV}$ photons from ${ }^{131} \mathrm{I}$ is high, problems with septal penetration for an HE collimator also occur, causing a decrease in image quality. It has been reported from simulations that the contrast of ${ }^{131}$ I-MIBG SPECT is only $70 \%$ of that of ${ }^{123}$ I-MIBG SPECT. ${ }^{81}$

\section{Other imaging techniques CT}

CT is widely used for localization of PC/PGL due to the high availability, low cost, and fast performance. With CT, PC tumors $>0.5-1 \mathrm{~cm}$ can be detected. ${ }^{62,84,85}$ Overall, a sensitivity of $86 \%-100 \%$ and a specificity of $50 \%-98 \%$ have been reported (Table 6). For intra-adrenal tumors $(>3 \mathrm{~cm})$, the sensitivity was high for unilateral adrenal tumors, while much lower values were obtained for bilateral tumors, as could be expected when little or no adrenal medullary tissue is present as reference. ${ }^{60,80,84-87}$ For the detection of only PC, a sensitivity of $94 \%-100 \%$ was reported, while for PGL or recurrent PC, the sensitivity was reduced to $57 \%-89 \%$. For PGL or recurrent tumors $>1 \mathrm{~cm}$ in diameter, a sensitivity of $77 \%-98 \%$ and a specificity of $29 \%-92 \%$ were reported. ${ }^{33}$ The sensitivity for CT was lower in some studies, and the 
Table 6 Sensitivity and specificity of CT for diagnosis of PC/PGL

\begin{tabular}{|c|c|c|c|}
\hline CT & $\begin{array}{l}\text { No. of patients and tumor } \\
\text { type according to the authors }\end{array}$ & Sensitivity (\%) & Specificity (\%) \\
\hline Francis et al ${ }^{10}$ & $\mathrm{n}=32 \mathrm{PC}$ & $\begin{array}{l}89 \text { - extra-adrenal } \\
100 \text { - intra-adrenal } \\
100 \text { - metastasis (when CT was } \\
\text { preformed with MIBG as guide) } \\
0 \text { - metastasis (when CT was } \\
\text { performed before MIBG) }\end{array}$ & Not reported \\
\hline Quint et al ${ }^{85}$ & $\begin{array}{l}\mathrm{n}_{\text {primary }}=13 \\
\mathrm{n}_{\text {recurrent }}=7 \\
\mathrm{PC}+\mathrm{PGL} \\
\text { Bias - patients selected after } \\
\text { positive }{ }^{|3|} \mid \text { scintigraphy }\end{array}$ & $\begin{array}{l}77-\text { primary } \\
57-\text { recurrent }\end{array}$ & Not reported \\
\hline Bravo and Saha ${ }^{132}$ & $\mathrm{n}=109 \mathrm{PC}$ & 98 & 70 \\
\hline Maurea et $\mathrm{al}^{77}$ & $\begin{array}{l}n_{\text {before surgery }}=21 \mathrm{PC}+\mathrm{PGL} \\
\mathrm{n}_{\text {after surgery }}=19 \mathrm{PC}+\mathrm{PGL}\end{array}$ & $\begin{array}{l}100 \text { - before surgery } \\
77 \text { - after surgery } \\
\text { Before surgery - } 14 \text { benign and } \\
3 \text { malignant } \\
\text { After surgery - } 9 \text { malignant } \\
\text { and } 3 \text { benign }\end{array}$ & $\begin{array}{l}50 \text { - before surgery } \\
83 \text { - after surgery }\end{array}$ \\
\hline Lucon et $\mathrm{al}^{78}$ & $\mathrm{n}=34 \mathrm{PC}$ & $\begin{array}{l}94-\text { total } \\
100-\text { abdominal }\end{array}$ & Not reported \\
\hline Jalil et $\mathrm{al}^{86}$ & $n=263 P C+P G L$ & $\begin{array}{l}89 \text { - total } \\
94-\text { adrenal total } \\
100 \text { - unilateral } \\
66 \text { - bilateral } \\
64 \text { - extra-adrenal }\end{array}$ & $98-$ total \\
\hline Furuta et $a^{68}$ & $\mathrm{n}=45 \mathrm{PC}$ & 100 & 61 \\
\hline Mannelli et a ${ }^{87}$ & $n=226 P C$ & $\begin{array}{l}99 \text { - intra-adrenal } \\
91 \text { - extra-adrenal }\end{array}$ & Not reported \\
\hline Goldstein et al $\left.\right|^{139}$ & $\mathrm{n}=34 \mathrm{PC}$ & 94 & 97 \\
\hline Witteles et $\mathrm{a}^{58}$ & $\mathrm{n}=26 \mathrm{PC}$ & 89 & Not reported \\
\hline Huang et $\mathrm{a}^{80}$ & $\mathrm{n}=25 \mathrm{PC}$ & $\begin{array}{l}96 \\
100-\text { unilateral }\end{array}$ & 92 \\
\hline Van der Harst et al ${ }^{75}$ & $\begin{array}{l}\mathrm{n}=70 \mathrm{PC} \\
\text { Sensitivity and specificity calculated } \\
\text { on lesions }(\mathrm{n}=84) \text { not on patients }\end{array}$ & 93 & Not reported \\
\hline Berglund et al ${ }^{140}$ & $\mathrm{n}=25 \mathrm{PC}$ & 100 & 50 \\
\hline Lumachi et al ${ }^{69}$ & $\mathrm{n}=32 \mathrm{PC}$ & 90 & 93 \\
\hline Timmers et $\mathrm{al}^{5}$ & $\mathrm{n}=26$ nonmetastatic PGL & 100 & Not reported \\
\hline
\end{tabular}

Abbreviations: PC, pheochromocytoma; PGL, paraganglioma; CT, computed tomography; MIBG, metaiodobenzylguanidine.

lowest specificity $(50 \%)$ was reported for patients prior to surgery.

In the past years, the $\mathrm{CT}$ technique has rapidly developed with multidetector techniques and more sensitive detectors. This will enable the possibility to detect smaller tumors than before. Still, however, the problem with discrimination between tumor and normal tissue remains. Contrast-enhanced CT may give higher sensitivity and specificity. ${ }^{88}$ The use of contrast agents for $\mathrm{CT}$ has long been avoided due to induction of hypertensive crisis in patients with PC using high-osmolar (ionic) contrast agents, but a recent study has indicated that low-osmolar (nonionic) contrast agents may be used in patients with PC not treated with adrenergic blockade. ${ }^{89}$

\section{MRI}

MRI has been widely used for diagnosis and follow-up of PC, both with and without gadolinium enhancement, and chemical shift imaging has been used to differentiate from cortical adenomas. With MRI, a sensitivity of $83 \%-100 \%$ and a specificity of $50 \%-100 \%$ have been reported (Table 7). For PC, the sensitivity was $96 \%-100 \%$, while for PGL, recurrent $\mathrm{PC}$, or malignant $\mathrm{PC}$, the sensitivity was reduced to $85 \%-88 \%$.

The standard MRI sequences used for PC/PGL localizations are T1-weighted and T2-weighted sequences. In T1-weighted images, the PC will appear as hypo or isointense, with signal intensity similar or lower than that 
Table 7 Sensitivity and specificity of MRI for diagnosis of PC and/or PGL

\begin{tabular}{|c|c|c|c|}
\hline MRI & $\begin{array}{l}\text { No. of patients and tumor } \\
\text { type according to the authors }\end{array}$ & Sensitivity (\%) & Specificity (\%) \\
\hline Quint et a ${ }^{85}$ & $\begin{array}{l}\mathrm{n}_{\text {primary }}=13 \\
\mathrm{n}_{\text {recurrent }}=7 \\
\text { Bias - patients selected after positive } \\
{ }^{3} \mid \text { I scintigraphy }\end{array}$ & $\begin{array}{l}92-\text { primary } \\
86 \text { - recurrent preop }\end{array}$ & Not reported \\
\hline Bravo and Saha ${ }^{132}$ & $\mathrm{n}=40 \mathrm{PC}$ & 100 & 67 \\
\hline Maurea et $\mathrm{al}^{77}$ & $\begin{array}{l}\mathrm{n}_{\text {before surgery }}=21 \\
\mathrm{n}_{\text {after surgery }}=19 \\
\mathrm{PC}+\mathrm{PGL} \\
\mathrm{TI} \text { and T2 }\end{array}$ & $\begin{array}{l}100 \text { - before surgery } \\
85 \text { - after surgery } \\
\text { Before surgery - } 14 \text { benign } \\
\text { and } 3 \text { malignant } \\
\text { After surgery - } 9 \text { malignant } \\
\text { and } 3 \text { benign }\end{array}$ & $\begin{array}{l}50 \text { - before surgery } \\
83 \text { - after surgery }\end{array}$ \\
\hline Lucon et al ${ }^{78}$ & $\mathrm{n}=18 \mathrm{PC}$ & 100 & Not reported \\
\hline Jalil et al ${ }^{86}$ & $\mathrm{n}=47 \mathrm{PC}+\mathrm{PGL} \mathrm{TI}$ and $\mathrm{T} 2$ & $\begin{array}{l}96 \text { - total } \\
97 \text { - adrenal total } \\
97 \text { - unilateral } \\
100 \text { - bilateral } \\
88 \text { - extra-adrenal }\end{array}$ & $100-$ total \\
\hline Goldstein et al $\left.\right|^{139}$ & $\mathrm{n}=12 \mathrm{PC}$ & 83 & 100 \\
\hline Witteles et $\mathrm{al}^{58}$ & $\mathrm{n}=12 \mathrm{PC}$ & 100 & Not reported \\
\hline Lumachi et a ${ }^{69}$ & $\mathrm{n}=32 \mathrm{PC} \mathrm{TI}$ and $\mathrm{T} 2$ & 93 & 93 \\
\hline Timmers et $\mathrm{al}^{5}$ & $\mathrm{n}=26$ nonmetastatic $\mathrm{PGL}$ & 100 & Not reported \\
\hline
\end{tabular}

Abbreviations: PC, pheochromocytoma; PGL, paraganglioma; MRI, magnetic resonance imaging.

of the liver and kidneys. However, the signal intensity will be enhanced in the presence of hemorrhage/hematoma or malignancy. ${ }^{36,90}$ In T2-weighted images, PC will appear hyperintense with up to 3 times the signal of the liver. ${ }^{44,85,86}$ However, the hyperintense signal from PC in T2-weighted images is not specific; edematous and necrotic adrenocortical metastases also show this behavior. ${ }^{44}$ In one study, T2-weighted MRI was found to be the most sensitive compared with ${ }^{131}$ I-MIBG and/or CT. ${ }^{86}$ Nevertheless, both T1-weighted and T2-weighted sequences are routinely used. The reason is that although T2-weighted images also make lesion characterization possible, T1-weighted images are necessary to detect tumors that cannot be distinguished from the adjacent fat on T2-weighted images. ${ }^{85}$

Another possibility with MRI is diffusion-weighted imaging (DWI). PC/PGL has high signal intensity in DWI due to increased cellularity, resulting in restriction of the diffusion of water molecules. DWI has been shown to offer advantages in imaging metastases, especially lymph node and liver metastases. However, the specificity of DWI is poor and the depiction of normal lymph nodes and other normal structures is very common. It is, therefore, recommended that DWI should be used together with ordinary T1-weighted and T2-weighted imaging. ${ }^{79}$

MRI has the advantage that imaging is less disturbed by distorted anatomy after surgery compared to CT, which is important when examining recurrent $\mathrm{PC} / \mathrm{PGL} .{ }^{86} \mathrm{MRI}$ is better than CT in detecting PGL, although the spatial resolution of MRI has been somewhat lower than that of CT. ${ }^{44,86,91}$ MRI has a superior tissue contrast when compared to $\mathrm{CT}$, which makes the use of paramagnetic contrast agents less necessary. There is a risk with contrast agents for inducing allergic reactions. In patients with PC, contrast agents can also induce a hypertensive crisis, which can be life-threatening..$^{84,86,91}$ Otherwise, the use of contrast agents in MRI may have some advantages. It gives the possibility to analyze the vascularity of the lesions and also to differentiate between solid and cystic masses. ${ }^{44}$ MRI does not use ionizing radiation, which makes it highly suited for imaging of pregnant women and children. ${ }^{44,69,86}$

\section{Comparison between MIBG, $C T$, and MRI}

There exists some controversy about which imaging technique (CT, MRI, and MIBG scintigraphy) should be used as standard and which should only be used in special cases. The controversy is understandable because of the many advantages and disadvantages that exist for each of the image modalities.

One advantage with MIBG scintigraphy is that it allows for identification of the lesion and also supplies both anatomic and functional information. ${ }^{84,92}$ It also has a low rate of both 
false-positive and false-negative results. ${ }^{41}$ The possibility of whole-body imaging with a single administration of MIBG makes it very cost-effective ${ }^{41,85,91}$ and especially well suited to localize $\mathrm{PGL}$ and recurrent $\mathrm{PC}$ as well as malignant PC/PGL. ${ }^{44,48,58,85,92}$

Disadvantages with MIBG scintigraphy are lower spatial resolution, poor visualization of anatomical details, and poor 3-dimensional localization. ${ }^{76,91}$ In this respect, both CT and MRI are superior to MIBG scintigraphy. Today, the introduction of hybrid techniques, for example SPECT/CT, has reduced the last drawback mentioned above.

In patients, prior to adrenal surgery, the use of CT or MRI as the initial imaging technique is justified. PC is often benign and located in the adrenals for which both $\mathrm{CT}$ and MRI have a high sensitivity of detection. ${ }^{54,77,78,87,93,94} \mathrm{MIBG}$ can be used in conjunction with $\mathrm{CT}$ and MRI to confirm a CA-handling tumor.

On the other hand, the use of MIBG scintigraphy as the initial imaging technique has also been discussed. With its whole-body screening potential, it can rule out extra-adrenal disease and act as a guide to subsequent CT and MRI investigations. This procedure can considerably raise the sensitivity of CT and MRI examination in the detection of PC. $54,60,69,91$

Tumors detected after surgery can be de novo tumors in hereditary disease or recurrences of a malignant PC/PGL. In a study comparing the sensitivity for detection of PC/PGL in patients prior to and after adrenal surgery, the proportion of patients with malignant disease was much higher after surgical treatment, indicating a higher sensitivity for recurrent disease (malignant PC/PGL) with MIBG. ${ }^{77}$ When they compared the data with CT and MRI, opposite results were obtained. The sensitivity for CT or MRI was reduced by more than $20 \%$, indicating a diminished detectability for malignant disease, while the specificity was increased in these patients. The results from these studies indicate that MIBG is also most useful in the detection of extra-adrenal tumors and metastases and tumors in patients with recurrent disease. . $3,48,77,91^{-1}$

However, there are arguments against the routine use of MIBG. Three studies challenge the use of MIBG to any larger extent. In all studies, MIBG revealed no extra information about the extent of the disease and in no cases did MIBG alter the management of the disease. They all state that in low-risk patients with sporadic unilateral PC, it is not economically acceptable to perform MIBG scintigraphy, but they agree that MIBG can be helpful in cases with recurrence and extra-adrenal lesions. ${ }^{93,95,96}$

Some of the drawbacks with planar scintigraphy with ${ }^{123} \mathrm{I}-\mathrm{MIBG}$ are effectively reduced using ${ }^{123} \mathrm{I}-\mathrm{MIBG}$ SPECT.
SPECT is more sensitive than planar imaging, but the difference is small. The main difference between the two lies in the certainty of detection. The certainty with which lesions are detected is significantly enhanced, and SPECT makes it easier to evaluate adrenals with low uptake. This contributes to a more definitive diagnosis. Another advantage of SPECT is that the 3-dimensional location of the lesion can be determined. ${ }^{71,97}$

\section{Other scintigraphic techniques Somatostatin receptor scintigraphy}

Another scintigraphic method of detecting PC/PGL is by somatostatin receptor scintigraphy (SRS) with the radiolabeled somatostatin analog octreotide, usually ${ }^{111}$ In-[DTPA-D$\mathrm{Phe}^{1}$ ]-octreotide (Figure 1A). The requirement for successful imaging is a reasonably high expression of somatostatin receptors (SSTRs), especially of subtype 2 and 5 by the tumor cells. Our own pilot studies on the quantitative SSTR mRNA expression using reverse transcriptase-polymerase chain reaction have shown relatively low levels of SSTR1 and SSTR2 in PC/PG versus very high levels in midgut carcinoids (<300 vs 9000 per $1000 \beta$-actin copies). The tumor/blood activity concentration ratios in vivo for radiolabeled somatostatin analogs for PC/PG were limited to values around 40 (in two patients), but more tumor biopsy data are required before any firm conclusion on the uptake can be made. ${ }^{37}$

Although the sensitivity for detection of benign PC has been shown to be low, ${ }^{75} \mathrm{SRS}$ can have a place in the evaluation for PC/PGL when malignancy is suspected. The reported detection efficiency of SRS varies. In some studies, ${ }^{131} \mathrm{I} /{ }^{123} \mathrm{I}-\mathrm{MIBG}$ was shown superior to SRS, ${ }^{98,99}$ while in other studies, the opposite relationship was found. ${ }^{75,100}$ However, SRS might be valuable for detection of MIBGnegative metastases. ${ }^{75,98,101,102}$ One study demonstrated the accumulation of radiolabeled octreotide in sites not found with other imaging modalities, but several of these findings were probably false positive..$^{99}$

SRS is well suited to diagnose parasympathetic PGL. A reported sensitivity of $93 \%$ was found with SRS, while with ${ }^{123} \mathrm{I}-\mathrm{MIBG}$, the sensitivity was only $44 \%$. Both the number of lesions detected and the intensity of uptake were superior with SRS compared with MIBG. ${ }^{63,103}$

\section{PET procedures}

PET imaging is another way to depict PC/PGL. The general drawback of PET imaging is the short half-time of most of the used radionuclide, while the spatial resolution of PET is superior to that of scintigraphy. Recently, the use of PET/CT 
systems with image fusion of PET and CT images may improve tumor detection. Several radiopharmaceuticals have been used in PET imaging for the evaluation of PC/PGL. The MIBG analogs ${ }^{124} \mathrm{I}-\mathrm{MIBG}$, meta- $\left[{ }^{76} \mathrm{Br}\right]$ bromobenzylguanidine ( $\left.{ }^{76} \mathrm{Br}-\mathrm{MBBG}\right)$, and $4-\left[{ }^{18} \mathrm{~F}\right]$-fluoro-3-iodobenzylguanidine $\left({ }^{18} \mathrm{~F}-\mathrm{FIBG}\right)$ have been suggested and used in a few studies. Others are FDG, ${ }^{18} \mathrm{~F}$-DOPA, 6- $\left[{ }^{18} \mathrm{~F}\right]$-fluorodopamine (FDA), ${ }^{11} \mathrm{C}$-hydroxyephedrine $\left({ }^{11} \mathrm{C}\right.$-HED), and ${ }^{11} \mathrm{C}$-epinephrine. The physical data on the radionuclides used for PET are given in Table 1.

${ }^{124} \mathrm{I}-\mathrm{MIBG}$ has been proposed in planning for ${ }^{131} \mathrm{I}-\mathrm{MIBG}$ radionuclide therapy and has been used in a pilot study on patients. ${ }^{104}$ Labeling techniques to obtain high-specific activity has been developed. ${ }^{105}$ The ${ }^{124}$ I-MIBG imaging of xenografted cells expressing the human NET gene in animals has been successful, ${ }^{106,107}$ but to our knowledge, no clinical studies have yet been reported. ${ }^{76} \mathrm{Br}-\mathrm{MBBG}$ has been produced and has similar pharmacokinetic behavior as MIBG. ${ }^{108,109}{ }^{124}$ I-MIBG and ${ }^{176} \mathrm{Br}-\mathrm{MBBG}$ have probably not been further used due to the low availability of radionuclides. Therefore, a ${ }^{18} \mathrm{~F}$-labeled MIBG analog was produced, ${ }^{18} \mathrm{~F}$-FIBG, which showed similar binding and pharmacokinetic properties in mice as MIBG, ${ }^{110}$ but no pilot studies in man have yet been presented.

FDG is taken up by all tissues with high metabolic rate, including malignant tumors, and is thus a nonspecific method. ${ }^{11-113}$ Despite the nonspecific nature of the uptake, it has been speculated that malignant PC/PGL might accumulate FDG faster and to a higher extent than benign PC/PGL. ${ }^{111}$ The sensitivity to detect benign PC/PGL is poor, but the use of FDG PET in malignant PC/PGL has advantages. ${ }^{111}$ High sensitivity has been reported; MIBG detects more lesions and has better detection of bone and lung metastases, while FDG PET has shown promising results in the detection of lymph node metastases. ${ }^{79,114}$ FDG PET seems especially promising in detecting PC/PGL that has failed to accumulate MIBG, and it has been found that the combination of the two modalities successfully detected all lesions. ${ }^{111,113}$

In addition, FDA has proven effective in the detection of malignant PC/PGL (Figure 2). FDA is a CA precursor that binds to the cell membrane NET. In two studies, FDA PET correctly demonstrated all patients with malignant disease. ${ }^{12,115}$ FDA PET may also have a role in the detection of benign PC. However, FDA also accumulates in the normal adrenal gland which, as with ${ }^{123} \mathrm{I}-\mathrm{MIBG}$, may obscure the detection of PC. ${ }^{116}$ FDA was proven superior to ${ }^{131} \mathrm{I}-\mathrm{MIBG}$ in both sensitivity and intensity of uptake and showed lesions not detected by either MIBG, CT, or MRI. ${ }^{112}$ However, since FDA binds to cell membrane NET, aggressive malignant
PC/PGL can lose their uptake capacity of FDA and then can give false-negative results. In such cases, FDG has been proven a superior method. ${ }^{103,117}$

DOPA is a precursor to DA, and one study reported that using ${ }^{18} \mathrm{~F}$-DOPA, all primary benign PGL tumors were successfully visualized in all patients who were examined. High uptake of ${ }^{18} \mathrm{~F}$-DOPA was shown in most lesions and ${ }^{18} \mathrm{~F}$-DOPA PET was found superior to ${ }^{123} \mathrm{I}-\mathrm{MIBG}$. Furthermore, no uptake in the normal adrenal gland was observed. ${ }^{118}$ Another study demonstrated a higher uptake of ${ }^{18} \mathrm{~F}$-DOPA in benign than in malignant PC/PGL, which makes the use of ${ }^{18} \mathrm{~F}$-DOPA PET in malignant PC/PGL questionable. ${ }^{119}{ }^{18} \mathrm{~F}$-DOPA PET can be used in conjunction with carbidopa. Carbidopa is a drug 'which decreases the decarboxylation and subsequent renal clearance of DOPA'. By the use of this drug, an enhanced uptake was seen in PC/PGL, which could potentially enhance the sensitivity. ${ }^{119}$

${ }^{11} \mathrm{C}-\mathrm{HED}$, which is a synthetic CA, has been used successfully to locate PC/PGL. ${ }^{120-122}{ }^{11} \mathrm{C}-\mathrm{HED}$ is rapidly accumulated in PC/PGL and within $5 \mathrm{~min}$, the lesions can be seen, with increased accumulation over time. The uptake of ${ }^{11} \mathrm{C}$-HED is higher than that of MIBG (better image contrast), and ${ }^{11} \mathrm{C}-\mathrm{HED}$ PET has a much higher sensitivity and specificity than ${ }^{131}$ I-MIBG. In a comparative study on PC/PGL, both ${ }^{123} \mathrm{I}-\mathrm{MIBG}$ SPECT/CT and ${ }^{11} \mathrm{C}-\mathrm{HED}$ PET/CT gave a sensitivity and specificity of $100 \%$, but PET/CT visualized more lesions. ${ }^{65}$ Although SPECT suffers from lower spatial resolution compared with PET, it can still be used, as ${ }^{11} \mathrm{C}$-HED PET has the drawback of high normal uptake in the liver, which may obscure lesions.

${ }^{11} \mathrm{C}$ can also be bound to EPI. In the first study, a high sensitivity was reported with rapid uptake of ${ }^{11} \mathrm{C}$-EPI, and the method might be complementary to MIBG, especially when MIBG fails to accumulate. ${ }^{123}$ EPI is avidly transported into the presynaptic nerve terminal via a type 1 uptake and is stored in secretory granules in a similar manner as NE. More studies are needed to clinically evaluate the usefulness of ${ }^{11} \mathrm{C}$-EPI versus the other scintigraphic methods.

\section{Comparison between scintigraphic methods}

In a cohort of patients with nonmetastatic and metastatic PC/PGL, the imaging properties of ${ }^{123}$ I-MIBG scintigraphy, FDA PET, and SRS were compared on a per-patient basis. ${ }^{102}$ The overall sensitivity was $90 \%$ for FDA PET, $76 \%$ for MIBG scintigraphy, and $22 \%$ for SRS. On a per-region basis, the overall sensitivity was $75 \%$ for FDA PET, $63 \%$ for MIBG scintigraphy, and $64 \%$ for SRS. In patients with metastatic 
PC, FDA PET localized lesions that SRS did not, but, on the other hand, SRS localized numerous lesions that were not detected by FDA PET. Both types of investigations were superior to ${ }^{123} \mathrm{I}-\mathrm{MIBG}$ scintigraphy (Figure 2). The authors concluded that FDA PET should be used to diagnose PC/PGL if the technique is available, due to its high sensitivity. Otherwise, ${ }^{123} \mathrm{I}-\mathrm{MIBG}$ scintigraphy (for nonmetastatic or adrenal PC) and SRS (for metastatic PC/PGL) are the first choices. $^{102}$

Although SRS seems to be of limited use for detection of benign solitary/adrenal PCs, ${ }^{8,102}$ SRS can reveal extra-adrenal or metastatic disease not visualized by MIBG. ${ }^{99,101,102,124}$ It has been suggested that MIBG scintigraphy probably gives a better overall detection rate compared with SRS for malignant PC. ${ }^{101}$ However, the MIBG uptake is, in general, lower in malignant PC due to a reduced expression of NET by less well-differentiated cells, which might limit the sensitivity. It has also been suggested that tumors of low differentiation might have higher SSTR expression. ${ }^{125}$ Patients with malignant PC might, therefore, have negative MIBG scintigraphy but positive SRS examination. ${ }^{75,101,102}$ Patients with predominant SRS-positive lesions had rapidly progressive disease at clinical and biochemical follow-up, which implies that SRS may provide prognostic information. ${ }^{102}$ Furthermore, in patients with positive SRS and negative-MIBG scintigraphy, therapy using radiolabeled somatostatin analogs, such as ${ }^{177} \mathrm{Lu}$-octreotate, might be better suited than ${ }^{131}$ I-MIBG..${ }^{4,126}$

In a recent comparative study, Timmers et al addressed the optimal functional imaging modality $\left({ }^{18} \mathrm{~F}\right.$-DOPA PET, ${ }^{18} \mathrm{~F}$-FDG PET, ${ }^{18} \mathrm{~F}$-FDA PET, and ${ }^{123}$ I-MIBG scintigraphy) to localize PGL and if genotype influenced the imaging results. ${ }^{5}$ Discrepant results in previous studies relate to heterogeneous patient series regarding location (adrenal or extra-adrenal, abdominal, thoracic, or head and neck tumors), malignancy, and hereditary tumor forms. Their results show that nonmetastatic tumors were equally well imaged by all four functional techniques (Table 8). Their study confirmed previous studies, where ${ }^{123} \mathrm{I}$-MIBG had high sensitivity for primary tumors but low for metastases. It has even been claimed that the only indication for this technique in metastatic disease is uptake studies prior to ${ }^{131} \mathrm{I}-\mathrm{MIBG}$ therapy. Of the techniques studied, MIBG and FDA utilize the NET and VMAT transporters, while tyrosine is internalized into the cell via the amino acid transporter to be converted to DOPA. FDG utilizes a glucose transporter (Figure 3). ${ }^{18} \mathrm{~F}$-DOPA PET had a similar sensitivity profile as ${ }^{123} \mathrm{I}-\mathrm{MIBG}$ with high detection rate for primary tumors but low for metastases (Table 8 ). The best imaging results were obtained with FDG PET/CT (88\%) and FDA PET/CT (78\%) in nonmetastatic lesions with somewhat lower sensitivity for metastatic lesions (74\% and $76 \%$, respectively). It is somewhat surprising that a nonspecific method like FDG has equal results as a CA-specific method like FDA PET.

Previous studies on hereditary tumors showed that FDA PET was superior to diagnose both VHL-associated and MEN 2-associated tumors, while FDG PET had a high sensitivity to diagnose patients with SDHB-associated malignancy (Table 8). ${ }^{74}$ The poor performance of ${ }^{131} \mathrm{I}-\mathrm{MIBG}$ in VHL tumors may be related to limited expression of NET in these patients. ${ }^{127}$ In a subgroup analysis in the study by Timmers et al, both FDA PET and FDG PET had high sensitivity ( $82 \%$ and $83 \%$, respectively) to detect metastatic SDHB tumors in comparison with the poor results using ${ }^{18} \mathrm{~F}$-DOPA (20\%) and ${ }^{123} \mathrm{I}-\mathrm{MIBG}(57 \%) .{ }^{5}$ The reason for the discrepant results of the CA-specific molecules ${ }^{18} \mathrm{~F}$-DOPA and FDA, both utilizing the same amino acid transporter,

Table 8 Sensitivity for detection of PGL in a prospective observational study of 52 patients by Timmers et al for various imaging modalities

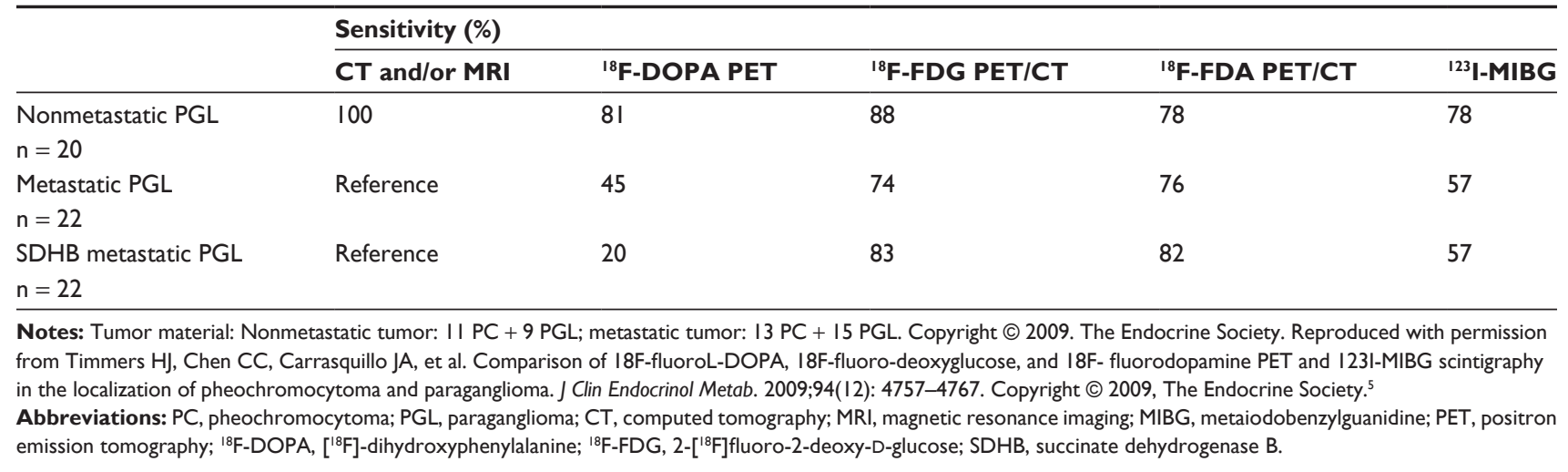




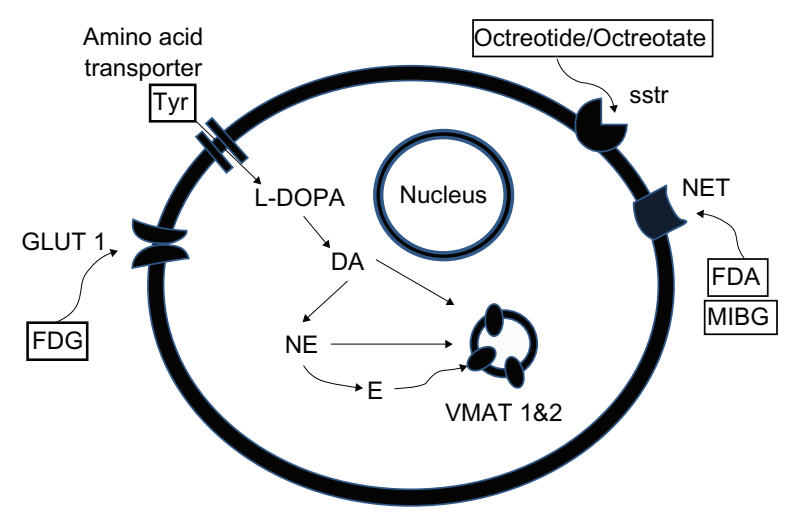

Figure 3 Targets for functional imaging of chromaffin cels and PC/PG (from left to right): The glucose transporter GLUTI (target for FDG); the amino acid transporter (responsible for transport of L-tyrosine, which is essential for the intracellular CA synthesis - DA, NE and E via L-DOPA - which are transported into the secretory granules via VMATs); sstr (subtypes sstr 2 and 5 are important for binding and intenalisation of the somatostatin analogs octreotide and octreotate), and the NE transporter NET (target for MIBG and FDA).

is obscure. It may be related to more rapid metabolism of DOPA or different affinity to the VMAT-transporter system and low retention in the secretory granules. FDG uptake is an indicator of high-metabolic rate, but in the tumors with the loss of SDHB activity and upregulation of hypoxia genes, there is a shift from oxidative phosphorylation to aerobic glycolysis (Warburg effect). ${ }^{128}$ This switch to less effective energy metabolism may explain a higher glucose need by the tumor, that is, higher FDG uptake.

\section{Conclusion and future prospects}

Since the introduction of MIBG scintigraphy, no clear increase in sensitivity and specificity for PC/PGL can be found. Instead, there is a large variation in these values between studies, both for ${ }^{131} \mathrm{I}-\mathrm{MIBG}$ and for ${ }^{123} \mathrm{I}-\mathrm{MIBG}$, probably reflecting differences in experience between different hospitals. The number of examinations performed with ${ }^{123}$ I-MIBG has increased with time, probably due to better availability of ${ }^{123}$ I. Thus, SPECT in MIBG scintigraphy has become more widely used, with better capacity to delineate smaller tumors. It is, however, not clear if the use of ${ }^{123} \mathrm{I}-\mathrm{MIBG}$ has improved the clinical outcome of the patients with PC/PGL.

Today, very few clinical studies comparing different scintigraphic-imaging strategies, including choice of radiopharmaceuticals, image acquisition, processing, and evaluation, have been performed that clearly show the best technique. One major reason is probably that it concerns rare tumor types, and few patients can be recruited per time period at a single hospital. It would be of great interest to establish well-designed and well-controlled clinical multicenter studies to improve diagnostic routines for $\mathrm{PC} / \mathrm{PGL}$.

In the future, it is likely that PET substances like ${ }^{18} \mathrm{~F}$-DOPA and ${ }^{18} \mathrm{~F}$-DA will be good complements to MIBG and somatostatin analogs in scintigraphy. It has already been suggested that FDA PET should be the first-line alternative because of its high sensitivity. It is also possible that different imaging strategies should be used dependent on the genotype of the tumor.

\section{Acknowledgments}

This work was supported by the Swedish Cancer Society, the Sahlgrenska Academy (the government ALF agreement), the Swedish Research Council, the King Gustav V Jubilee Clinic Cancer Research Foundation, and the Royal Society of Arts and Sciences in Gothenburg.

\section{Disclosure}

The authors report no conflicts of interest in this work.

\section{References}

1. Chrisoulidou A, Kaltsas G, Ilias I, Grossman AB. The diagnosis and management of malignant phaeochromocytoma and paraganglioma. Endocr Relat Cancer. 2007;14(3):569-585.

2. Wangberg B, Muth A, Khorram-Manesh A, et al. Malignant pheochromocytoma in a population-based study: survival and clinical results. Ann N Y Acad Sci. 2006;1073:512-516.

3. Ahlman H. Malignant pheochromocytoma: state of the field with future projections. Ann N Y Acad Sci. 2006;1073:449-464.

4. Forssell-Aronsson E, Bernhardt P, Wängberg B, Kölby $\mathrm{L}$, Nilsson $\mathrm{O}$, Ahlman H. Aspects on radionuclide therapy in malignant pheochromocytomas. Ann N Y Acad Sci. 2006;1073: 498-504.

5. Timmers HJ, Chen CC, Carrasquillo JA, et al. Comparison of $18 \mathrm{~F}$-fluoroL-DOPA, 18F-fluoro-deoxyglucose, and 18F-fluorodopamine PET and 123I-MIBG scintigraphy in the localization of pheochromocytoma and paraganglioma. J Clin Endocrinol Metab. 2009;94(12): 4757-4767.

6. Francis IR, Korobkin M. Pheochromocytoma. Radiol Clin North Am. 1996;34(6):1101-1112.

7. Erickson JD, Schafer MK, Bonner TI, Eiden LE, Weihe E. Distinct pharmacological properties and distribution in neurons and endocrine cells of two isoforms of the human vesicular monoamine transporter. Proc Natl Acad Sci U S A. 1996;93(10):5166-5171.

8. Shulkin BL, Ilias I, Sisson JC, Pacak K. Current trends in functional imaging of pheochromocytomas and paragangliomas. Ann N Y Acad Sci. 2006;1073:374-382.

9. Kaltsas GA, Papadogias D, Grossman AB. The clinical presentation (symptoms and signs) of sporadic and familial chromaffin cell tumours (phaeochromocytomas and paragangliomas). Front Horm Res. 2004;31: 61-75.

10. Lenders JW, Pacak K, Walther MM, et al. Biochemical diagnosis of pheochromocytoma: which test is best? JAMA. 2002;287(11):1427-1434.

11. DeLellis R, Lloyd R, Heitz P. WHO Classification of Tumours Pathology and Genetics of Tumours of Endocrine Organs. Lyon, France: IARC Press; 2004:147-150. 
12. Sibal L, Jovanovic A, Agarwal SC, et al. Phaeochromocytomas presenting as acute crises after beta blockade therapy. Clin Endocrinol (Oxf). 2006;65(2):186-190.

13. Bravo EL, Tagle R. Pheochromocytoma: state-of-the-art and future prospects. Endocr Rev. 2003;24(4):539-553.

14. Karagiannis A, Mikhailidis DP, Athyros VG, Harsoulis F. Pheochromocytoma: an update on genetics and management. Endocr Relat Cancer. 2007;14(4):935-956.

15. Elder EE, Elder G, Larsson C. Pheochromocytoma and functional paraganglioma syndrome: no longer the 10\% tumor. J Surg Oncol. 2005;89(3):193-201.

16. Mannelli M, Simi L, Gagliano MS, et al. Genetics and biology of pheochromocytoma. Exp Clin Endocrinol Diabetes. 2007;115(3):160-165.

17. Young AL, Baysal BE, Deb A, Young WF Jr. Familial malignant catecholamine-secreting paraganglioma with prolonged survival associated with mutation in the succinate dehydrogenase B gene. J Clin Endocrinol Metab. 2002;87(9):4101-4105.

18. Baysal BE, Ferrell RE, Willett-Brozick JE, et al. Mutations in SDHD, a mitochondrial complex II gene, in hereditary paraganglioma. Science. 2000;287(5454):848-851.

19. Kaelin WG Jr. SDH5 mutations and familial paraganglioma: somewhere Warburg is smiling. Cancer Cell. 2009;16(3):180-182.

20. Astuti D, Latif F, Dallol A, et al. Gene mutations in the succinate dehydrogenase subunit SDHB cause susceptibility to familial pheochromocytoma and to familial paraganglioma. Am J Hum Genet. 2001;69(1): 49-54.

21. Yang Y, Valera VA, Padilla-Nash HM, et al. UOK 262 cell line, fumarate hydratase deficient (FH-/FH-) hereditary leiomyomatosis renal cell carcinoma: in vitro and in vivo model of an aberrant energy metabolic pathway in human cancer. Cancer Genet Cytogenet. 2010;196(1):45-55.

22. Hao HX, Khalimonchuk O, Schraders M, et al. SDH5, a gene required for flavination of succinate dehydrogenase, is mutated in paraganglioma. Science. 2009;325(5944):1139-1142.

23. Bayley JP, Devilee P. Warburg tumours and the mechanisms of mitochondrial tumour suppressor genes. Barking up the right tree? Curr Opin Genet Dev. 2010;20(3):324-329.

24. Amar L, Bertherat J, Baudin E, et al. Genetic testing in pheochromocytoma or functional paraganglioma. J Clin Oncol. 2005;23(34):8812-8818.

25. Brouwers FM, Eisenhofer G, Tao JJ, et al. High frequency of SDHB germline mutations in patients with malignant catecholamine-producing paragangliomas: implications for genetic testing. J Clin Endocrinol Metab. 2006;91(11):4505-4509.

26. Lack EE, Lloyd RV, Carney JA, Woodruff JW; Association of Directors of Anatomic and Surgical Pathology. Recommendations for the reporting of extra-adrenal paragangliomas. The Association of Directors of Anatomic and Surgical Pathology. Hum Pathol. 2003;34(2): 112-113.

27. Ilias I, Sahdev A, Reznek RH, Grossman AB, Pacak K. The optimal imaging of adrenal tumours: a comparison of different methods. Endocr Relat Cancer. 2007;14(3):587-599.

28. Korobkin M, Francis IR, Kloos RT, Dunnick NR. The incidental adrenal mass. Radiol Clin North Am. 1996;34(5):1037-1054.

29. Wieland DM, Wu J, Brown LE, Mangner TJ, Swanson DP, Beierwaltes WH. Radiolabeled adrenergi neuron-blocking agents: adrenomedullary imaging with [131I]iodobenzylguanidine. J Nucl Med. 1980;21(4):349-353.

30. Kline RC, Swanson DP, Wieland DM, et al. Myocardial imaging in man with I-123 meta-iodobenzylguanidine. J Nucl Med. 1981;22(2): 129-132.

31. Sisson JC, Frager MS, Valk TW, et al. Scintigraphic localization of pheochromocytoma. N Engl J Med. 1981;305(1):12-17.

32. Shapiro B, Gross MD, Shulkin B. Radioisotope diagnosis and therapy of malignant pheochromocytoma. Trends Endocrinol Metab. 2001;12(10): 469-475.

33. Ilias I, Pacak K. Anatomical and functional imaging of metastatic pheochromocytoma. Ann N Y Acad Sci. 2004;1018:495-504.

34. Sisson JC, Shulkin BL. Nuclear medicine imaging of pheochromocytoma and neuroblastoma. Q J Nucl Med. 1999;43(3):217-223.
35. Shapiro B, Gross MD. Radiochemistry, biochemistry, and kinetics of 131I-metaiodobenzylguanidine (MIBG) and 123I-MIBG: clinical implications of the use of 123I-MIBG. Med Pediatr Oncol. 1987;15(4): $170-177$.

36. Van Gils AP, Falke TH, van Erkel AR, et al. MR imaging and MIBG scintigraphy of pheochromocytomas and extraadrenal functioning paragangliomas. Radiographics. 1991;11(1):37-57.

37. Kolby L, Bernhardt P, Johanson V, et al. Can quantification of VMAT and SSTR expression be helpful for planning radionuclide therapy of malignant pheochromocytomas? Ann N Y Acad Sci. 2006;1073:491-497.

38. Alavi A, Basu S. Planar and SPECT imaging in the era of PET and PET-CT: can it survive the test of time? Eur J Nucl Med Mol Imaging. 2008;35(8):1554-1559.

39. Vaidyanathan G, Friedman HS, Keir ST, Zalutsky MR. Evaluation of meta-[211 At]astatobenzylguanidine in an athymic mouse human neuroblastoma xenograft model. Nucl Med Biol. 1996;23(6):851-856.

40. Vaidyanathan G, Affleck DJ, Alston KL, et al. A kit method for the high level synthesis of [211 At]MABG. Bioorg Med Chem. 2007;15(10): 3430-3436.

41. Kurtaran A, Traub T, Shapiro B. Scintigraphic imaging of the adrenal glands. Eur J Radiol. 2002;41(2):123-130.

42. Campeau RJ, Garcia OM, Correa OA, Rege AB. Pheochromocytoma: diagnosis by scintigraphy using iodine 131 metaiodobenzylguanidine. South Med J. 1991;84(10):1221-1230.

43. Ackery DM, Tippett PA, Condon BR, Sutton HE, Wyeth P. New approach to the localisation of phaeochromocytoma: imaging with iodine-131-meta-iodobenzylguanidine. Br Med J (Clin Res Ed). 1984; 288(6430):1587-1591.

44. Brink I, Hoegerle S, Klisch J, Bley TA. Imaging of pheochromocytoma and paraganglioma. Fam Cancer. 2005;4(1):61-68.

45. Troncone L, Rufini V, Danza FM, et al. Radioiodinated metaiodobenzylguanidine (*I-MIBG) scintigraphy in neuroblastoma: a review of 160 studies. J Nucl Med Allied Sci. 1990;34(4):279-288.

46. Hattner RS, Pounds TR, Matthay KK. Normal cerebellar MIBG localization. Implications in the interpretation of delayed scans. Clin Nucl Med. 1994;19(11):985-988.

47. Dwamena BA, Zempel S, Klopper JF, van Heerden B, Wieland D, Shapiro B. Brain uptake of iodine-131 metaiodobenzylguanidine following therapy of malignant pheochromocytoma. Clin Nucl Med. 1998;23(7):441-445.

48. Elgazzar AH, Gelfand MJ, Washburn LC, et al. I-123 MIBG scintigraphy in adults. A report of clinical experience. Clin $\mathrm{Nucl} \mathrm{Med.}$ 1995;20(2):147-152.

49. Lynn MD, Shapiro B, Sisson JC, et al. Portrayal of pheochromocytoma and normal human adrenal medulla by $\mathrm{m}-[123 \mathrm{I}]$ iodobenzylguanidine: concise communication. J Nucl Med. 1984;25(4):436-440.

50. Lynn MD, Shapiro B, Sisson JC, et al. Pheochromocytoma and the normal adrenal medulla: improved visualization with I-123 MIBG scintigraphy. Radiology. 1985;155(3):789-792.

51. Lindberg S, Fjalling M, Jacobsson L, Jansson S, Tisell LE. Methodology and dosimetry in adrenal medullary imaging with iodine-131 MIBG. J Nucl Med. 1988;29(10):1638-1643.

52. Roelants V, Goulios C, Beckers C, Jamar F. Iodine-131-MIBG scintigraphy in adults: interpretation revisited? J Nucl Med. 1998;39(6): 1007-1012.

53. Nakajo M, Shapiro B, Copp J, et al. The normal and abnormal distribution of the adrenomedullary imaging agent m-[I-131]iodobenzylguanidine (I-131 MIBG) in man: evaluation by scintigraphy. $J$ Nucl Med. 1983;24(8):672-682.

54. Mozley PD, Kim CK, Mohsin J, Jatlow A, Gosfield E 3rd, Alavi A. The efficacy of iodine-123-MIBG as a screening test for pheochromocytoma. J Nucl Med. 1994;35(7):1138-1144.

55. Paltiel HJ, Gelfand MJ, Elgazzar AH, et al. Neural crest tumors: I-123 MIBG imaging in children. Radiology. 1994;190(1):117-121.

56. Bombardieri E, Aktolun C, Baum RP, et al. 131I/123I-metaiodobenzylguanidine (MIBG) scintigraphy: procedure guidelines for tumour imaging. Eur J Nucl Med Mol Imaging. 2003;30(12): BP132-BP139. 
57. Shapiro B, Copp JE, Sisson JC, Eyre PL, Wallis J, Beierwaltes WH. Iodine-131 metaiodobenzylguanidine for the locating of suspected pheochromocytoma: experience in 400 cases. $J$ Nucl Med. 1985;26(6): 576-585.

58. Witteles RM, Kaplan EL, Roizen MF. Sensitivity of diagnostic and localization tests for pheochromocytoma in clinical practice. Arch Intern Med. 2000;160(16):2521-2524.

59. Hoefnagel CA, Voute PA, de Kraker J, Marcuse HR. Radionuclide diagnosis and therapy of neural crest tumors using iodine-131 metaiodobenzylguanidine. J Nucl Med. 1987;28(3): 308-314.

60. Francis IR, Glazer GM, Shapiro B, Sisson JC, Gross BH. Complementary roles of CT and 131I-MIBG scintigraphy in diagnosing pheochromocytoma. AJR Am J Roentgenol. 1983;141(4):719-725.

61. Montravers F, Coutris G, Sarda L, Mensch B, Talbot JN. Utility of thallium-201 and iodine-123 metaiodobenzylguanidine in the scintigraphic detection of neuroendocrine neoplasia. Eur J Nucl Med. 1993; 20(11):1070-1077.

62. Bhatia KS, Ismail MM, Sahdev A, et al. 123I-metaiodobenzylguanidine (MIBG) scintigraphy for the detection of adrenal and extra-adrenal phaeochromocytomas: CT and MRI correlation. Clin Endocrinol (Oxf). 2008;69(2):181-188.

63. Koopmans KP, Jager PL, Kema IP, Kerstens MN, Albers F, Dullaart RP. 111In-octreotide is superior to 123I-metaiodobenzylguanidine for scintigraphic detection of head and neck paragangliomas. $J \mathrm{Nucl} \mathrm{Med}$. 2008;49(8):1232-1237.

64. Wiseman GA, Pacak K, O'Dorisio MS, et al. Usefulness of 123I-MIBG scintigraphy in the evaluation of patients with known or suspected primary or metastatic pheochromocytoma or paraganglioma: results from a prospective multicenter trial. J Nucl Med. 2009;50(9): $1448-1454$.

65. Franzius C, Hermann K, Weckesser M, et al. Whole-body PET/CT with $11 \mathrm{C}$-meta-hydroxyephedrine in tumors of the sympathetic nervous system: feasibility study and comparison with 123I-MIBG SPECT/CT. J Nucl Med. 2006;47(10):1635-1642.

66. Rozovsky K, Koplewitz BZ, KrauszY, et al. Added value of SPECT/CT for correlation of MIBG scintigraphy and diagnostic CT in neuroblastoma and pheochromocytoma. AJR Am J Roentgenol. 2008;190(4): 1085-1090.

67. Ozer S, Dobrozemsky G, Kienast O, et al. Value of combined XCT/SPECT technology for avoiding false positive planar (123)I-MIBG scintigraphy. Nuklearmedizin. 2004;43(5):164-170.

68. Furuta N, Kiyota H, Yoshigoe F, Hasegawa N, Ohishi Y. Diagnosis of pheochromocytoma using [123I]-compared with [131I]-metaiodobenzylguanidine scintigraphy. Int J Urol. 1999;6(3):119-124.

69. Lumachi F, Tregnaghi A, Zucchetta P, et al. Sensitivity and positive predictive value of CT, MRI and 123I-MIBG scintigraphy in localizing pheochromocytomas: a prospective study. Nucl Med Commun. 2006;27(7):583-587.

70. Cecchin D, Lumachi F, Marzola MC, et al. A meta-iodobenzylguanidine scintigraphic scoring system increases accuracy in the diagnostic management of pheochromocytoma. Endocr Relat Cancer. 2006;13(2):525-533

71. Nielsen JT, Nielsen BV, Rehling M. Location of adrenal medullary pheochromocytoma by I-123 metaiodobenzylguanidine SPECT. Clin Nucl Med. 1996;21(9):695-699.

72. Shulkin BL, Shapiro B, Francis IR, Dorr R, Shen SW, Sisson JC. Primary extra-adrenal pheochromocytoma: positive I-123 MIBG imaging with negative I-131 MIBG imaging. Clin Nucl Med 1986;11(12):851-854.

73. Nakatani T, Hayama T, Uchida J, Nakamura K, Takemoto Y, Sugimura K. Diagnostic localization of extra-adrenal pheochromocytoma: comparison of (123)I-MIBG imaging and (131)I-MIBG imaging. Oncol Rep. 2002;9(6):1225-1227.

74. Havekes B, Lai EW, Corssmit EP, Romijn JA, Timmers HJ, Pacak K. Detection and treatment of pheochromocytomas and paragangliomas: current standing of MIBG scintigraphy and future role of PET imaging. QJ Nucl Med Mol Imaging. 2008;52(4):419-429.
75. van der Harst E, de Herder WW, Bruining HA, et al. [(123)I] metaiodobenzylguanidine and [(111)In]octreotide uptake in begnign and malignant pheochromocytomas. J Clin Endocrinol Metab. 2001;86(2):685-693.

76. Nguyen HH, Proye CA, Carnaille B, Combemale F, Pattou FN, Huglo D. Tumour size: the only predictive factor for 131I MIBG uptake in phaeochromocytoma and paraganglioma. Aust NZJ Surg. 1999;69(5): 350-353.

77. Maurea S, Cuocolo A, Reynolds JC, Neumann RD, Salvatore M. Diagnostic imaging in patients with paragangliomas. Computed tomography, magnetic resonance and MIBG scintigraphy comparison. Q J Nucl Med. 1996;40(4):365-371.

78. Lucon AM, Pereira MA, Mendonça BB, Halpern A, Wajchenbeg BL, Arap S. Pheochromocytoma: study of 50 cases. J Urol. 1997;157(4): 1208-1212.

79. Takano A, Oriuchi N, Tsushima Y, et al. Detection of metastatic lesions from malignant pheochromocytoma and paraganglioma with diffusionweighted magnetic resonance imaging: comparison with $18 \mathrm{~F}-\mathrm{FDG}$ positron emission tomography and 123I-MIBG scintigraphy. Ann Nucl Med. 2008;22(5):395-401.

80. Huang H-H, Wang P-W, Huang Y-E, Hsu Y-H, Wu Y-C, Lee C-H. Localization of pheochromocytoma: I-131 MIBG scintigraphy correlated with computed tomography. Ann Nucl Med Sci. 2001;14(2): $67-74$.

81. Rault E, Vandenberghe S, van Holen R, de Beenhouwer J, Staelens S, Lemahieu I. Comparison of image quality of different iodine isotopes (I-123, I-124, and I-131). Cancer Biother Radiopharm. 2007;22(3): 423-430.

82. Yang Y-W, Chen J-C, Chang C-J, Cheng C-Y, Wang S-J. Evaluation of collimator choice and scatter correction on ${ }^{123}$ I SPECT images. $\mathrm{Nucl}$ Instrum Methods Phys Res. 2007;584(1):204-211.

83. Dobbeleir AA, Hambye AS, Franken PR. Influence of highenergy photons on the spectrum of iodine-123 with low- and medium-energy collimators: consequences for imaging with 123Ilabelled compounds in clinical practice. Eur J Nucl Med. 1999;26(6): 655-658.

84. Bravo EL. Pheochromocytoma: new concepts and future trends. Kidney Int. 1991;40(3):544-556.

85. Quint LE, Glazer GM, Francis IR, Shapiro B, Chenevert TL. Pheochromocytoma and paraganglioma: comparison of MR imaging with CT and I-131 MIBG scintigraphy. Radiology. 1987;165(1): 89-93.

86. Jalil ND, Pattou FN, Combemale F, et al. Effectiveness and limits of preoperative imaging studies for the localisation of pheochromocytomas and paragangliomas: a review of 282 cases. French Association of Surgery (AFC), and The French Association of Endocrine Surgeons (AFCE). Eur J Surg. 1998;164(1):23-28.

87. Mannelli M, Ianni L, Cilotti A, Conti A. Pheochromocytoma in Italy: a multicentric retrospective study. Eur J Endocrinol. 1999;141(6): 619-624.

88. Ilias I, Pacak K. Current approaches and recommended algorithm for the diagnostic localization of pheochromocytoma. J Clin Endocrinol Metab. 2004;89(2):479-491.

89. Baid SK, Lai EW, Wesley RA, et al. Brief communication: radiographic contrast infusion and catecholamine release in patients with pheochromocytoma. Ann Intern Med. 2009;150(1):27-32.

90. Disick GI, Palese MA. Extra-adrenal pheochromocytoma: diagnosis and management. Curr Urol Rep. 2007;8(1):83-88.

91. Velchik MG, Alavi A, Kressel HY, Engelman K. Localization of pheochromocytoma: MIBG [correction of MIGB], CT, and MRI correlation. J Nucl Med. 1989;30(3):328-336.

92. Troncone L, Rufini V, Montemaggi P, Danza FM, Lasorella A, Mastrangelo R. The diagnostic and therapeutic utility of radioiodinated metaiodobenzylguanidine (MIBG). 5 years of experience. Eur J Nucl Med. 1990;16(4-6):325-335.

93. Greenblatt DY, ShenkerY, Chen H. The utility of metaiodobenzylguanidine (MIBG) scintigraphy in patients with pheochromocytoma. Ann Surg Oncol. 2008;15(3):900-905. 
94. Maurea S, Cuocolo A, Reynolds JC, et al. Iodine-131-metaiodobenzylguanidine scintigraphy in preoperative and postoperative evaluation of paragangliomas: comparison with CT and MRI. J Nucl Med. 1993;34(2):173-179.

95. Miskulin J, Shulkin BL, Doherty GM, Sisson JC, Burney RE, Gauger PG. Is preoperative iodine 123 meta-iodobenzylguanidine scintigraphy routinely necessary before initial adrenalectomy for pheochromocytoma? Surgery. 2003;134(6):918-922; discussion 22-23.

96. Mihai R, Gleeson F, Roskell D, Parker A, Sadler G. Routine preoperative (123)I-MIBG scintigraphy for patients with phaeochromocytoma is not necessary. Langenbecks Arch Surg. 2008;393(5):725-727.

97. Gelfand MJ, Elgazzar AH, Kriss VM, Masters PR, Golsch GJ. Iodine123-MIBG SPECT versus planar imaging in children with neural crest tumors. J Nucl Med. 1994;35(11):1753-1757.

98. Kopf D, Bockisch A, Steinert H, et al. Octreotide scintigraphy and catecholamine response to an octreotide challenge in malignant phaeochromocytoma. Clin Endocrinol (Oxf). 1997;46(1):39-44.

99. Tenenbaum F, Lumbroso J, Schlumberger M, et al. Comparison of radiolabeled octreotide and meta-iodobenzylguanidine (MIBG) scintigraphy in malignant pheochromocytoma. J Nucl Med. 1995;36(1):1-6.

100. Kwekkeboom DJ, van Urk H, Pauw BK, et al. Octreotide scintigraphy for the detection of paragangliomas. J Nucl Med. 1993;34(6):873-878.

101. Kaltsas G, Korbonits M, Heintz E, et al. Comparison of somatostatin analog and meta-iodobenzylguanidine radionuclides in the diagnosis and localization of advanced neuroendocrine tumors. J Clin Endocrinol Metab. 2001;86(2):895-902.

102. Ilias I, Chen CC, Carrasquillo JA, et al. Comparison of 6-18Ffluorodopamine PET with 123I-metaiodobenzylguanidine and 111 in-pentetreotide scintigraphy in localization of nonmetastatic and metastatic pheochromocytoma. J Nucl Med. 2008;49(10):1613-1619.

103. Timmers HJ, Kozupa A, Chen CC, et al. Superiority of fluorodeoxyglucose positron emission tomography to other functional imaging techniques in the evaluation of metastatic SDHB-associated pheochromocytoma and paraganglioma. J Clin Oncol. 2007;25(16): 2262-2269.

104. Ott RJ, Tait D, Flower MA, Babich JW, Lambrecht RM. Treatment planning for 131I-mIBG radiotherapy of neural crest tumours using 124I-mIBG positron emission tomography. Br J Radiol. 1992;65(777): 787-791.

105. Amartey JK, Al-Jammaz I, Lambrecht RM. An efficient batch preparation of high specific activity. Appl Radiat Isot. 2001;54(5):711-714.

106. Chen N, Zhang Q, Yu YA, et al. A novel recombinant vaccinia virus expressing the human norepinephrine transporter retains oncolytic potential and facilitates deep-tissue imaging. Mol Med. 2009;15(5-6): 144-151.

107. Moroz MA, Serganova I, Zanzonico P, et al. Imaging hNET reporter gene expression with 124I-MIBG. J Nucl Med. 2007;48(5):827-836.

108. Valette H, Loc'h C, Mardon K, et al. Bromine-76-metabromobenzylguanidine: a PET radiotracer for mapping sympathetic nerves of the heart. J Nucl Med. 1993;34(10):1739-1744.

109. Loc'h C, Mardon K, Valette H, et al. Preparation and pharmacological characterization of [76Br]-meta-bromobenzylguanidine $([76 \mathrm{Br}]$ MBBG). Nucl Med Biol. 1994;21(1):49-55.

110. Vaidyanathan G, Affleck DJ, Zalutsky MR. Validation of 4-[fluorine-18] fluoro-3-iodobenzylguanidine as a positron-emitting analog of MIBG. J Nucl Med. 1995;36(4):644-650.

111. Shulkin BL, Thompson NW, Shapiro B, Francis IR, Sisson JC. Pheochromocytomas: imaging with 2-[fluorine-18]fluoro-2-deoxyD-glucose PET. Radiology. 1999;212(1):35-41.

112. Ilias I, Yu J, Carrasquillo JA, et al. Superiority of 6-[18F]-fluorodopamine positron emission tomography versus [131I]-metaiodobenzylguanidine scintigraphy in the localization of metastatic pheochromocytoma. J Clin Endocrinol Metab. 2003;88(9):4083-4087.

113. Shulkin BL, Koeppe RA, Francis IR, Deeb GM, Lloyd RV, Thompson NW. Pheochromocytomas that do not accumulate metaiodobenzylguanidine: localization with PET and administration of FDG. Radiology. 1993;186(3):711-715.
114. Han SJ, Kim TS, Jeon SW, et al. Analysis of adrenal masses by 18F-FDG positron emission tomography scanning. Int J Clin Pract. 2007;61(5):802-809.

115. Pacak K, Eisenhofer G, Carrasquillo JA, Chen CC, Li ST, Goldstein DS. 6-[18F]fluorodopamine positron emission tomographic (PET) scanning for diagnostic localization of pheochromocytoma. Hypertension. 2001;38(1):6-8.

116. Timmers HJ, Carrasquillo JA, Whatley M, et al. Usefulness of standardized uptake values for distinguishing adrenal glands with pheochromocytoma from normal adrenal glands by use of 6-18F-fluorodopamine PET. J Nucl Med. 2007;48(12):1940-1944.

117. Mamede M, Carrasquillo JA, Chen CC, et al. Discordant localization of 2-[18F]-fluoro-2-deoxy-D-glucose in 6-[18F]-fluorodopamine- and [(123)I]-metaiodobenzylguanidine-negative metastatic pheochromocytoma sites. Nucl Med Commun. 2006;27(1):31-36.

118. Hoegerle S, Nitzsche E, Altehoefer C, et al. Pheochromocytomas: detection with 18F DOPA whole body PET - initial results. Radiology. 2002;222(2):507-512.

119. Timmers HJ, Hadi M, Carrasquillo JA, et al. The effects of carbidopa on uptake of 6-18F-Fluoro-L-DOPA in PET of pheochromocytoma and extraadrenal abdominal paraganglioma. J Nucl Med. 2007;48(10): 1599-1606.

120. Shulkin BL, Wieland DM, Schwaiger M, et al. PET scanning with hydroxyephedrine: an approach to the localization of pheochromocytoma. J Nucl Med. 1992;33(6):1125-1131.

121. Trampal C, Engler H, Juhlin C, Bergstrom M, Langstrom B. Pheochromocytomas: detection with $11 \mathrm{C}$ hydroxyephedrine PET. Radiology. 2004;230(2):423-428.

122. Mann GN, Link JM, Pham P, et al. [11C]metahydroxyephedrine and [18F]fluorodeoxyglucose positron emission tomography improve clinical decision making in suspected pheochromocytoma. Ann Surg Oncol. 2006;13(2):187-197.

123. Shulkin BL, Wieland DM, Shapiro B, Sisson JC. PET epinephrine studies of pheochromocytoma. J Nucl Med. 1995;36:229P.

124. De Herder WW, Kwekkeboom DJ, Valkema R, et al. Neuroendocrine tumors and somatostatin: imaging techniques. J Endocrinol Invest. 2005;28 Suppl International 11:132-136.

125. Behr TM, Behe M, Becker W. Diagnostic applications of radiolabeled peptides in nuclear endocrinology. Q J Nucl Med. 1999;43(3): 268-280.

126. Van Essen M, Krenning EP, de Jong M, Valkema R, Kwekkeboom DJ. Peptide Receptor Radionuclide Therapy with radiolabelled somatostatin analogues in patients with somatostatin receptor positive tumours. Acta Oncol. 2007;46(6):723-734.

127. Kaji P, Carrasquillo JA, Linehan WM, et al. The role of 6-[18F] fluorodopamine positron emission tomography in the localization of adrenal pheochromocytoma associated with von Hippel-Lindau syndrome. Eur J Endocrinol. 2007;156(4):483-487.

128. Warburg O. On respiratory impairment in cancer cells. Science. 1956;124(3215):269-270.

129. MIRD. Nuclear decay data in the MIRD format. Jan 21, 2011. Available from: http://www.nndc.bnl.gov/mird/. Accessed January 26, 2011.

130. Brown ML, Sheps SG, Sizemore G, et al. MIBG in the evaluation of suspected pheochromocytoma: Mayo Clinic experience. J Nucl Med. 1984;25:5

131. Swensen SJ, Brown ML, Sheps SG, et al. Use of 131I-MIBG scintigraphy in the evaluation of suspected pheochromocytoma. Mayo Clin Proc. 1985;60(5):299-304.

132. Bravo EL, Saha G. Preoperative localization of pheochromocytoma: a prospective comparison of I-131-metaiodobenzylguanidine and abdominal computed tomography [abstract]. In: Prog Fourth Eur Mtg Hypertens; 1989; Milan, Italy.

133. Clesham CJ, Kennedy A, Lavender JP, Dollery CT, Wilkins MR. Meta-iodobenzylguanidine (MIBG) scanning in the diagnosis of phaeochromocytoma. J Hum Hypertens. 1993;7(4): 353-356. 
134. van der Horst-Schrivers AN, Jager PL, Boezen HM, Schouten JP, Kema IP, Links TP. Iodine-123 metaiodobenzylguanidine scintigraphy in localising phaeochromocytomas - experience and meta-analysis. Anticancer Res. 2006;26(2B):1599-1604.

135. ICRP53. Annals of the ICRP Publication 53. Radiation Dose to Patients from Radiopharmaceuticals. Vol 18. Oxford, UK: Pergamon Press; 1987:331

136. ICRP80. Radiation Dose to Patients from Radiopharmaceuticals: Addendum 2 to ICRP Publication 53. Vol 28. Oxford, UK: Pergamon Press; 1998.

137. ICRP 53 Addendum 4. Radiation Dose to Patients from Radiopharmaceuticals: Addendum 4 to ICRP Publication 53. Oxford, UK: Pergamon Press; 2001.
138. ICRP 87. Managing Patient Dose in Computed Tomography. Vol 30. Oxford, UK: Pergamon Press; 2000.

139. Goldstein RE, O’Neill JA Jr, Holcomb GW 3rd, et al. Clinical experience over 48 years with pheochromocytoma. Ann Surg. 1999;229(6): 755-764; discussion 64-66.

140. Berglund AS, Hulthén UL, Manhem P, Thorsson O, Wollmer P, Törnquist C. Metaiodobenzylguanidine (MIBG) scintigraphy and computed tomography (CT) in clinical practice. Primary and secondary evaluation for localization of phaeochromocytomas. J Intern Med. 2001;249(3):247-251.

\section{Publish your work in this journal}

Reports in Medical Imaging is an international, peer-reviewed, open access journal publishing original research, reports, reviews and commentaries on all areas of medical imaging. The manuscript management system is completely online and includes a very quick and fair peer-review system, which is all easy to use.

\section{Dovepress}

Visit http://www.dovepress.com/testimonials.php to read real quotes from published authors. 